\title{
Historical Trends of Human Rights Gone Criminal
}

\author{
Mattia Pinto*
}

\begin{abstract}
While the traditional understanding of human rights is to restrain state authority to prevent abuses against the individual, in the last few decades human rights have been recast in a way that has made criminal law one of the main instruments for their promotion. The article explores how, since the 1970s, human rights have allowed penal power to move and expand around the globe. Five trends are explored: i) the rise of victims' rights in criminal proceedings; ii) the emergence of United Nations instruments focusing on human rights enforcements by means of criminal law; iii) the development of transitional justice; iv) the promotion of human rights in international criminal law; and v) the imposition of positive duties in criminal matters by human rights bodies. The article argues that the universality of human rights has enabled criminal justice projects to spread and expand over time and space, mixing domestic and international elements. Victims' rights advocates, NGOs, practitioners, academics, judges, and policymakers have been involved in this process. Yet, the expansion of penality by means of human rights has generally appeared as uncontroversial and important questions have been left unanswered. In particular, the assumptions underlying the idea that human rights require criminal accountability remain unexplored and unchallenged.
\end{abstract}

\section{INTRODUCTION}

On 26 November 2018, Human Rights Watch filed a submission with the Argentinian prosecutors, calling for criminal investigations and charges against Saudi Crown Prince Mohammed Bin Salman, who was expected to attend the G20 Summit in Buenos Aires. The human rights NGO highlighted Bin Salman's alleged complicity in war crimes in Yemen and in the murder of Jamal Khashoggi, the

\footnotetext{
* Mattia Pinto is a Ph.D. Candidate and teaching assistant in the Law Department at the London School of Economics and Political Science (LSE). His Ph.D. research analyzes the role that human rights play in fostering and legitimizing penal expansion. He holds degrees from the University of Bologna (Five Year Master of Law) and King's College London (LLM). Prior to joining LSE Law, Pinto worked as legal intern at the European Court of Human Rights (Registry) and at the International Criminal Court (Office of Public Counsel for the Defence), and as research assistant in international criminal law at King's College London.

I am very grateful for the comments and discussion with Peter Ramsay, Conor Gearty, Nicola Lacey, Gerry Simpson, Diletta Marchesi, Olivia Nantermoz Benoit-Gonin, Steven Malby, Salvatore Sapienza, Giulia Bosi, and Rebecca Nocella. I also benefited from thoughtful discussion and criticism at the LSE PhD Upgrade Conference in May 2019 and at the Queen Mary Postgraduate Legal Research Conference 2019 “Silver Linings” (June 2019).
} 
Washington Post columnist killed in Istanbul's Saudi consulate in October 2018. On 28 November, the Argentinean judiciary opened an investigation against the Saudi leader. Mohammed Bin Salman attended the summit, engaged in discussions with other world leaders, and left Argentina on 2 December. He was not arrested but had to spend the nights at the Buenos Aires's Saudi embassy, instead of in a hotel with his delegation.

In recent years, the use of human rights to trigger the application of criminal law has proliferated around the world at the international, regional, and domestic levels. This process transcends national borders not only because of the places where proceedings are held, the nationality of the victims and offenders, and the location of the wrongdoings, but also because of the widespread belief that the universal conception of human rights mandates criminal accountability, regardless of the context, implications, and practicability. The case of Mohammed Bin Salman is emblematic, because it involves human rights violations committed in Yemen and Turkey, the alleged implication of Saudi nationals, a victim who was resident in the United States (US), and a complaint filed by an international NGO with Argentinean prosecutors. In addition, this submission was highly symbolic, since the likelihood that the Saudi crown prince would be arrested, prosecuted, and punished in Argentina was quite low. Nonetheless, as Human Rights Watch executive director Kenneth Roth explained, human rights require "a clear message" to be sent, that the international community is committed to criminal accountability for serious wrongdoings. ${ }^{1}$ This example illustrates how it has become normal in international, regional, and domestic law to ask that perpetrators of human rights

1 G20: Argentine Probe of Saudi Crown Prince Advances, Human RigHTS Watch (HRW) (28 Nov. 2018), https://www.hrw.org/news/2018/11/28/g20-argentine-probe-saudi-crown-prince-advances. 
violations are held criminally accountable. ${ }^{2}$

This article provides a historical account of the role of human rights as drivers of penality. ${ }^{3} \mathrm{It}$ explores how, since the late 1970s, domestic, regional and international courts, policymakers, and civil society have invoked and used human rights to justify and expand penality. Penality is justified directly by appeal to human rights or indirectly when it is presented as necessary for human rights protection. A handful of studies have examined the growing importance of criminal prosecution in human rights projects. ${ }^{4}$ Yet, they generally focus on specific contexts or areas of law and overlook wider historical trends at the domestic, regional, and international levels that have made criminal law an essential element of human rights protection. This article fills this gap and makes an original contribution to research, by outlining trends in human rights protection through criminal law mechanisms in a variety of geographical and institutional contexts. An effort is made to analyze the interaction between the international, regional, and domestic levels and explore how discourses, norms, and practices of one level have influenced the others. The article is divided in five parts, each exploring a different but inter-connected trend of using human rights in the expansion of penality. It begins with the growing relevance of victims' rights in criminal proceedings. The second part shows the emergence of UN instruments focusing on human rights enforcement by means of criminal law measures. The third part deals with the enduring relevance of criminal law mechanisms in transitional justice projects. The fourth part presents the justificatory role of human rights in modern international criminal law, while the final part gives an overview on the incorporation of

${ }^{2}$ Leigh A. Payne, The Justice Paradox?, in Transnational Legal Orders 439, 439 (Terence C. Halliday \& Gregory Shaffer eds., 2015).

${ }^{3}$ In this article, the term "penality" is used to refer to the entire penal sphere, including its laws, sanctions, institutions, practices, discourses, and representations. See DAVID GARLAND, PUnishment AND Welfare: A History OF PENAL Strategies, at x (1985); David Garland, Penality and the Penal State, 51 Criminology 475, 476 (2013).

4 See, e.g., Anti-Impunity and the Human Rights Agenda, (Karen Engle, Zinaida Miller, \& Dennis M. Davis eds., 2016); Hani Sayed, The Regulatory Function of the Turn to Anti-impunity in the Practice of International Human Rights Law, 55 STANFORD J. INT'L L. 1 (2019); Natalie Sedacca, The "Turn" to Criminal Justice in Human Rights Law: An Analysis in the Context of the 2016 Colombian Peace Agreement, 19 HuM. RTS L. REV. 315 (2019). 
criminal law within the work of human rights bodies. The discussion presented in this article neither intends to suggest that all discourses of human rights justify and strengthen penality nor aspire to be exhaustive. Rather, it aims to explore how human rights have historically enabled penality to expand while criminal law has become an opportunity for advancing the human rights project. Ultimately, the article illustrates how the idea that human rights require penality has circulated through time and space in an unchallenged fashion. The actors involved have largely accepted this phenomenon as normal, rather than reflect on the choices that have been made and the effects that have derived. The role of human rights as sources of penality has gradually been normalized. ${ }^{5}$

\section{THE RISE OF VICTIMS'RIGHTS LANGUAGE}

Since the 1970s, the phenomenon of victims' rights in criminal proceedings has been at the heart of civil rights movements' and policymakers' concern both on the national and the international stage. ${ }^{6}$ While modern criminal trials have traditionally involved an exclusive relationship between the state and the defendant, in recent years many have argued that criminal justice should also take into account the interests of the parties affected by criminal wrongdoings. ${ }^{7}$ The study of victims of crime adopted a more practical and policy oriented perspective in the 1970s and 1980s, due to the combined efforts of both the women's human rights movement and conservative, law-and-order

\footnotetext{
5 Michel Foucault, Security, Territory, Population: Lectures at the Collège De France, 1977-78, 85 (Michel Senellart ed., Graham Burchell tran., 2007).

$[\mathrm{N}]$ ormalization consists first of all in positing a model, an optimal model that is constructed in terms of a certain result, and the operation of [...] normalization consists in trying to get people, movements, and actions to conform to this model, the normal being precisely that which can conform to this norm, and the abnormal that which is incapable of conforming to the norm.

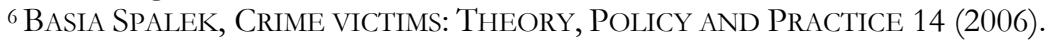

${ }^{7}$ Integrating A ViCTIM Perspective Within CRIMINAl JustiCe: International Debates, (Adam Crawford \& Jo Goodey eds., 2000).
} 
advocates. ${ }^{8}$ This development first occurred in North America and the United Kingdom (UK) and, later, in various other countries as well as internationally. ${ }^{9}$ The emergence of victim surveys (measuring the extent and nature of victimization) and academic interest in the characteristics of victimization (victimology) sustained a new attention toward victim harm. ${ }^{10}$ This focus, in turn, contributed to the rise of the victims' rights movement which, since the 1980s, has tried to improve victims' interaction with the criminal justice system and enhance therein the role of those affected by crime. ${ }^{11}$ Along with this "official” movement, victims' protection became the objective of numerous sectorial action groups "formed around identities in relation to race, gender, sexuality, disability and so forth" ("single-issue" victim advocacy groups). ${ }^{12}$ Today, the victims' rights movement is not homogeneous and, while in some countries victim advocates have not explicitly promoted punitive policies, in others (e.g. Austria, Germany, Japan, New Zealand, the US) they have at times expressed repressive impulses by conducting campaigns for harsher punishment or more incapacitating sentencing policy. ${ }^{13}$ This phenomenon occurred especially within single-issue victim advocacy groups, such as the women's rights movement. ${ }^{14}$ As Elizabeth Bernstein observes, feminists in different countries have increasingly turned to "carceral politics" to protect rights concerning bodily

\footnotetext{
${ }^{8}$ Robert Elias, The Politics of Victimization: Victims, Victimology, And human Rights 20 (1986); Wesley G. Skogan, Arthur J. Lurigio \& Robert C. Davis, Criminal Victimization, in VICTIMS OF CRIME: PrOBLEMS, POLICIES, AND Programs 7, 8 (Arthur J. Lurigio, Wesley G. Skogan, \& Robert C. Davis eds., 1990).

${ }^{9}$ Ivo Aertsen, Punitivity from a Victim's Perspective, in RESISTING Punitiveness In Europe 202, 210 (Sonja Snacken \& Els Dumortier eds., 2012).

${ }^{10}$ Leslie Sebba, "Victim-Driven" Criminalisation? Some Recent Trends in the Expansion of the Criminal Law, in REGULATING Deviance: The Redirection of Criminalisation AND the Futures of Criminal LAW 59, 63 (Bernadette McSherry, Alan Norrie, \& Simon Bronitt eds., 2009).

${ }^{11} \mathrm{Id}$. at 64.

12 SPALEK, supra note 6, at 134.

13 Aertsen, supra note 9, at 211; Sebba, supra note 10, at 66; MARKUS D. DubBER, VICTIMS IN THE WAR ON CRIME: THE UsE AND ABUSE OF Victims' Rights 1 (2002); Andrew Ashworth, Victim's Rights, Defendants' Rights and Criminal Procedure, in Integrating a Victim Perspective within Criminal Justice: International Debates 185, 185-86 (Adam Crawford \& Jo Goodey eds., 2000).

14 Aya Gruber, The Feminist War on Crime, 92 IowA L. REV. 741, 749-51 (2007); Dianne L. Martin, Retribution Revisited: A Reconsideration of Feminist Criminal Law Reform Strategies, 36 OSGOODE HALL L. J. 151, 168 (1998).
} 
and sexual integrity. ${ }^{15}$ Activists in the US, India, and China, for example, have sought to criminalize domestic violence, usually encouraging mandatory arrest of offenders and no-drop prosecution. ${ }^{16}$ Hate crime legislation is another area where the intersection of victims' rights, human rights, and criminal justice has given rise to an expanded criminalization. ${ }^{17}$

While the proposals of victims' organizations have been varied, they have mainly focused on reinforcing victims' position in criminal proceedings. ${ }^{18}$ This process started in the 1980 s at the domestic level, especially in the US with the Victims of Crime Act of 1984 and the adoption of "victims' bills of rights" in several states of the Union. ${ }^{19}$ Then, it continued at the international level..$^{20}$ Between 1983 and 1987, the Council of Europe implemented the European Convention on the Compensation of Victims of Violent Crimes (1983) and a series of recommendation for victims, including state compensation and assistance. ${ }^{21}$ In 1985, the UN published the Declaration of Basic Principles of Justice for Victims of Crime and Abuse of Power (UN Victims' Declaration) and in 1999 produced the UN Handbook on Justice for Victims, ${ }^{22}$ while the European Union (EU)

${ }^{15}$ Elizabeth Bernstein, Carceral Politics as Gender Justice? The "Traffic in Women" and Neoliberal Circuits of Crime, Sex, and Rights, 41 THEORY \& SOC’Y 233 (2012); Elizabeth Bernstein, The Sexual Politics of the "New Abolitionism,” 18 DIFFERENCES 128 (2007). Bernstein defines "carceral feminism" as "a [feminist] cultural and political formation in which previous generations' justice and liberation struggles are recast in carceral terms."

16 Sally Engle Merry, Transnational Human Rights and Local Activism: Mapping the Middle, 108 AM. ANTHROPOLOGIST 38 (2006).

${ }_{17}$ Mari J. Matsuda, Public Response to Racist Speech: Considering the Victim's Story, 87 MiCH. L. REV. 2320 (1989); Leslie J Moran, Affairs of the Heart: Hate Crime and the Politics of Crime Control, 12 LAW \& CRITIQUE 331, 340-42 (2001); DEAN Spade, Normal Life: Administrative ViolenCE, Critical Trans POLITICS, AND THE Limits OF LAW 2 (2015).

18 Gilbert Geis, Crime Victims: Practices and Prospects, in Victims of Crime: Problems, Policies, AND Programs 251, 252 (Robert C. Davis, Arthur J. Lurigio \& Wesley G. Skogan eds., 1990).

${ }^{19}$ US Victims of Crime Act of 1984, H.R.6403 (1984); Jo Goodey, An Overview of Key Themes, in INTEGRATING A VICTIM Perspective within Criminal Justice: International Debates 13, 19 (Adam Crawford \& Jo Goodey eds., 2000).

20 Adam Crawford, Introduction, in INTEgRATING A ViCTIM PERSPECTIVE WITHIN CRIMINAL JUSTICE: INTERNATIONAL DEBATES 1, 1 (Adam Crawford \& Jo Goodey eds., 2000).

${ }^{21}$ European Convention on the Compensation of Victims of Violent Crimes, ETS No. 116 (1983); Council of Europe, Recommendation of the Committee of Ministers to Member States on Participation of the Public in Crime Policy, R(83)7 (1983); Council of Europe, Recommendation of the Committee of Ministers to Member States on the Position of the Victim in the Framework of Criminal Law and Procedure, R(85)11 (1985); Council of Europe, Recommendation of the Committee of Ministers to Member States on Assistance to Victims and the Prevention of Victimisation, $\mathrm{R}(87) 21$ (1987).

22 UNGA, Declaration of Basic Principles of Justice for Victims of Crime and Abuse of Power, Res 40/34, U.N. Doc A/RES/40/34 (1985) [hereinafter Res. 40/34]; UNITED NATIONS OFFICE FOR DRUG CONTROL AND CRIME PREVENTION (UNODC), HANDBOOK ON JUSTICE FOR VICTIMS (1999). 
adopted the Framework Decision on the Standing of Victims in Criminal Proceedings in 2001, ${ }^{23}$ subsequently replaced by the Victim of Crime Directive in $2012 .^{24}$ The Rome Statute and the Rules of Procedure and Evidence of the International Criminal Court (ICC) also codified a comprehensive list of victims' rights in criminal proceedings. ${ }^{25}$ Thanks to these provisions and similar developments at the level of individual countries, today victims of crime have a far-reaching catalogue of fundamental rights in different stages of the criminal process, including participatory rights, right to receive information, and right to reparation. ${ }^{26}$ Discussion of victims' rights within criminal proceedings has often been distinct from human rights discourse, although human rights law increasingly deals with the matter. ${ }^{27}$ Since late 1980, the European Court of Human Rights (ECtHR), the Inter-American Court of Human Rights (IACtHR) and the UN Human Rights Committee (UNHRC) have interpreted provisions on the rights to fair trial and to an effective remedy as providing victims' rights within the criminal process. ${ }^{28}$ The recognition of victims' rights has sometimes gone beyond procedural rights to grant substantive rights as well, including the right to have the offender prosecuted and punished by a court. ${ }^{29}$

Though not overlapping, victims' rights and human rights have many points of contact. ${ }^{30}$ First, certain crimes are also human rights violations and the category of "crime victim" may overlap

${ }^{23}$ EU, Framework Decision on the Standing of Victims In Criminal Proceedings, OJ L82 (2001).

24 EU Directive 2012/29/EU of the European Parliament and of the Council of 25 October 2012 Establishing Minimum Standards on the Rights, Support and Protection of Victims of Crime, and Replacing Council Framework Decision 2001/220/JHA, (2012).

${ }_{25}$ Rome Statute of the International Criminal Court, adopted 17 July 1998, U.N. Doc. A/CONF.183/9 (1998), 2187 U.N.T.S. 90 (entered into force 1 July 2002).

${ }^{26}$ JONATHAN DOAK, ViCTIMS' RightS, HuMAN RigHTS AND CRIMINAL JUSTICE: RECONCEIVING THE ROLE OF THIRD PARTIES 115-58 (2008).

${ }_{27}$ Mykola Sorochinsky, Prosecuting Torturers, Protecting "Child Molesters": Toward a Power Balance Model of Criminal Process for International Human Rights Law, 31 MiCH. J. INT’L L. 157 (2009).

${ }_{28}$ Raquel Aldana-Pindell, An Emerging Universality of Justiciable Victims' Rights in the Criminal Process to Curtail Impunity for State-Sponsored Crimes, 26 HuM. RTS Q. 605, 622-46 (2004).

${ }^{29}$ Fernando Felipe Basch, The Doctrine of the Inter-American Court of Human Rights regarding States' Duty to Punish Human Rights Violations and Its Dangers, 23 AM. U. INT'L L. REV 195, 227-28 (2007).

30 ELIAS, supra note 8, at 8; Sandra Walklate, Victims' Needs, Rights and Justice, in THE RoUTLEDGE INTERNATIONAL HANDbOOK OF CRIMINOLOGY AND Human Rights 71 (Leanne Weber, Elaine Fishwick, \& Marinella Marmo eds., 2017). 
with the category of "human rights victim." For instance, violence against women and children, torture, enforced disappearance, and trafficking are all crimes as well as human rights abuses. Criminal victimization can be source of considerable suffering, not dissimilarly from human rights violations. In line with Robert Elias, we can consider certain crimes as violations of human rights, even though the perpetrator is a private individual and not the state. ${ }^{31}$ Second, the victims' rights movement has developed in parallel with the emergence of the human rights movement ${ }^{32}$ and in several circumstances the two groups have coincided, such as in the case of the battered-women's movement ${ }^{33}$ and the anti-trafficking campaigns. ${ }^{34}$ Today, several victim support activists describe their cause as a human rights campaign, by equating criminal victimization with human rights violations. While presenting their struggle in the language of human rights, these victim groups tend to turn away from social support and political struggle, and toward the promotion of criminal law. ${ }^{35}$ Third, in some cases, international bodies have recognized victims of human rights abuses as victims of crime, although the abuses to which the latter were subject were not criminalized in their country. ${ }^{36}$ For instance, the UN Victims' Declaration, implicitly referring to the wrongdoings committed in Latin America during the dictatorships, urges states to criminalize abuses of power and to provide remedies to victims of such abuses, as if they were victims of crime. Finally, victims' rights rhetoric is akin to the human rights one. Both victim and human rights discourse tend to present victims (of either crimes or human rights abuses) as innocent and sympathetic, and opposed

\footnotetext{
${ }^{31}$ ELIAS, supra note 8, at 205, 208.

32 ROBERT ELIAS, VICTIMS STILL: THE POLITICAL MANIPULATION OF CRIME VICTIMS 59-61 (1993).

${ }^{33}$ Lucy N. Friedman \& Minna Shulman, Domestic Violence: The Criminal Justice Response, in VICTIMS OF CRIME: PROBLEMS, Policies, AND Programs 87 (Arthur J. Lurigio, Wesley G. Skogan, \& Robert C. Davis eds., 1990).

${ }^{34}$ Bernstein, supra note 15.

35 Elizabeth Bernstein, Militarized Humanitarianism Meets Carceral Feminism: The Politics of Sex, Rights, and Freedom in Contemporary Antitrafficking Campaigns, 36 SIGNS 45-71, 50 (2010).

36 Sebba, supra note 10 , at 67.
} 
to evil and predatory offenders or perpetrators. ${ }^{37}$ The media spread images of insecurity, abuses, victimization and help create the trope of the "ideal-victim" that needs vindication for its suffering. ${ }^{38}$ This ideal-victim is applied to a wide variety of human misfortunes, from ordinary crimes to human rights violations. ${ }^{39}$ It creates a "culture of victimhood" 40 that is often used to support expanded penal policies and law-and-order thinking. ${ }^{41}$

Contemporary criminal justice discourses are soaked in the language of victims' rights. This trajectory was not inevitable. ${ }^{42}$ In its early days, the victim movement was primarily concerned with the recognition of victims' basic needs rather than with victims' rights, by offering emotional support and assistance to victims as well as concentrating on the causes of abuses. ${ }^{43}$ Only in the 1980s and 1990s has it become increasingly involved with promoting better provisions for victims within the terrain of criminal justice. ${ }^{44}$ At the time, the movement could question the ability of the criminal law in protecting victims' needs and interests, while focusing on alternative, non-criminal responses to victimization. Rather, despite criticism of criminal justice institutions for being blind in respect of those affected by crime, victim support organizations designated the criminal law and its sanctions as the primary responses to victims' suffering. ${ }^{45}$ The risk of "secondary victimization" deriving from the criminal justice system was not ascribed to the inability of criminal justice to provide social justice and victims' restoration, but to the failure of the adversarial model (and, to a

\footnotetext{
${ }^{37}$ Makau Mutua, Savages, Victims, and Saviors: The Metaphor of Human Rights, 42 HARVARD J. INT'L L. 201 (2001); DUBBER, supra note 13 , at 3 .

38 Jonathan Simon, Governing Through Crime: How the War on Crime Transformed American DEMOCRACY AND CREATED A CULTURE OF FEAR 135 (2007).

39 Aertsen, supra note 9, at 204.

40 Frank Furedi, Culture of FeAr: Risk-TAKing AND the Morality of LOW ExpeCtation (1997).

${ }^{41}$ David Garland, The Culture Of CONTROL: Crime AND SOCIAl Order IN CONTEMPORARY SOCIETY (2001).

${ }^{42}$ Kent Roach, Four Models of the Criminal Process, 89 J. Crim L. \& Criminology 671, 715 (1999).

${ }^{43}$ DOAK, supra note 26 , at 9.

${ }^{44}$ Id. at 9; ELIAS, VICTIMS STILL, supra note 32, at 52.

${ }^{45}$ Roach, supra note 42, at 705-06.
} 
lesser extent, the inquisitorial model) to grant the victim effective participatory rights. ${ }^{46}$ By claiming that victims should be put at the heart of criminal justice, not only do victim activists lobby for a reform of the criminal justice system, but they also legitimize and endorse its expansion. ${ }^{47}$ Although many of victims' expectations are said to be in the procedural sphere rather than in the achievement of a punitive outcome, ${ }^{48}$ reliance on criminal justice institutions means in practice their embrace at the expense of other, non-punitive, solutions. ${ }^{49}$ Even restorative measures are usually incorporated into the existing punitive framework. ${ }^{50}$ More victims' rights do not automatically mean more punitiveness, but their indirect influence (both conceptual and rhetorical) can play a part and eventually result in expanded penality. ${ }^{51}$ As observed by Leslie Sebba, "victim-driven" criminalization has ultimately resulted in the inclusion of new offenses (e.g. stalking, sexual harassment, new forms of child abuse, hate crimes, holocaust denial, and human trafficking), the expansion of the scope of some existing crimes (e.g. rape) and compression of traditional defenses (e.g. self-defense and provocation). ${ }^{52}$ Governments may also use the rhetoric of victims' rights to disguise policies that are primarily aimed at benefiting the interest of the state rather than the victims. ${ }^{53}$ This phenomenon has been labelled "populist punitiveness" ${ }^{54}$ or "penal populism"55 and involves expanding penality and curbing defendants' due process rights by invoking better protection for victims. ${ }^{56}$ The state takes advantage of the request for more victims' rights and

\footnotetext{
46 Sebba, supra note 10, at 64.

${ }^{47}$ Roach, supra note 42 , at 703.

48 Aertsen, supra note 9, at 207.

${ }^{49}$ Gruber, supra note 14, at 800.

${ }^{50}$ Lucia Zedner, Reparation and Retribution: Are They Reconcilable?, 57 MODERN L. REV. 228 (1994).

51 Aertsen, supra note 9, at 219; Sebba, supra note 10 at 65.

52 Sebba, supra note 10 , at 60 .

53 DOAK, supra note 26, at 11.

54 Anthony Bottoms, The Philosophy and Politics of Punishment and Sentencing, in THE POLITICS OF SENTENCING REFORM 17, 40 (Christopher M. V. Clarkson \& Rod Morgan eds., 1995).

55 John Pratt, Penal Populism (2007); Nicola lacey, The Prisoners’ Dilemma: Political Economy and PUNISHMENT IN CONTEMPORARY DEMOCRACIES 3-54 (2008).

${ }^{56}$ DUBBER, supra note 13.
} 
citizens' fear of crime to express increased penal control. ${ }^{57}$ As Markus Dubber puts it, "[i]t's the very real suffering of personal victims of violent crime that justifies the state's usurpation of ever greater powers of investigation and control." 58

To sum up, academics, criminal justice reformers, victim support activists, victim surveys, and the media have all played a role in making the victim of crime socially visible. ${ }^{59}$ Yet, the language of victims' rights, intertwined with human rights discourse, has also become a "key vehicle both for the transnationalization of carceral politics and for folding back these policies into the domestic terrain in a benevolent $[. .$.$] guise. { }^{\prime 60}$ Victims' rights discourse has played a role in legitimizing penality domestically and internationally and giving crime repression a "new and powerful human and rightsbearing face." ${ }^{61}$ But it has also contributed to reshaping the concept of crime as private matter of interpersonal violence as opposed to an offence against the public interest. ${ }^{62}$ This perspective, compared to the traditional state centered approach to criminal law, is also more consistent with the acceptance of a human rights framework. Criminal law, no longer the instrument to preserve solely public security and public interests, can now be used to secure victims from ordinary crimes, but also from atrocities and human rights violations. It turns into a tool of social reform and a protection for vulnerable individuals. ${ }^{63}$

\section{THE UPSURGE OF PENALITY IN THE UN HUMAN RIGHTS PROJECT}

\footnotetext{
57 Peter Ramsay, The Theory of V ulnerable Autonomy and the Legitimacy of Civil Preventative Orders, in REGULATING DEVIANCE: THE REDIRECTION OF CRIMINALISATION AND THE FUTURES OF CRIMINAL LAW, supra note 10; SimON, supra note 38 at 96.

${ }^{58}$ DUBBER, supra note 13 , at 6.

${ }^{59}$ Aertsen, supra note 9, at 203.

${ }^{60}$ Bernstein, Carceral Politics as Gender Justice, supra note 15, at 235.

${ }^{61}$ Roach, supra note 42, at 691.

${ }^{62}$ DUBBER, supra note 13 , at 4.

63 Augusto Jobim do Amaral, The Penal Policy of Human Rights, 1 ZEITSCHRIFT FÜR INTERNATIONALE StrafrechtSDOGMATIK 61 (2013); MARIA LuCIA KARAM, RECUPERAR O DESEjo DA LIBERDADE E CONTER O PoDER PUNITIVO 4 (2009).
} 
In the last forty years, various bodies under the aegis of the UN have promoted a number of conventions, declarations, and other non-binding instruments expressing the idea that states ought to provide criminal justice mechanisms for serious breaches of human rights standards. Around the same time as the rise of victims' rights at the national level, at the global stage the UN has been a key actor in promoting human rights and legitimizing their enforcement through criminal law. Efforts to set out state obligations to criminalize, prosecute, and punish human rights violations in international treaties might even be dated back to the Convention on the Prevention and Punishment of the Crime of Genocide (Genocide Convention), adopted in 1948 in the wake of the Second World War. ${ }^{64}$ However, the context of the postwar period, marked by the horror of the Nazi genocide and the Nuremberg trials, may explain the early drafting of this treaty. ${ }^{65}$ In addition, the Genocide Convention is not part of the UN human rights project, both because it focuses only on a too narrow situation and because it was originally presented in opposition to the Universal Declaration on Human Rights (1948), ${ }^{66}$ passed the day after. ${ }^{67}$

Within the UN system, the first obligation to criminalize human rights breaches can be found in the International Convention on the Elimination of all Forms of Racial Discrimination, adopted in $1965 .{ }^{68}$ Article 4 requires that states 'declare an offence punishable by law' various forms of hate speech and racial discrimination. ${ }^{69}$ The drafting of this article was deemed controversial at

\footnotetext{
${ }^{64}$ Convention on the Prevention and Punishment of the Crime of Genocide, adopted 9 Dec. 1948, G.A. Res. 260 (III), U.N. GAOR, 3d Sess., U.N. Doc. A/RES/3/260 (1948), 78 U.N.T.S. 277 (entered into force 12 Jan. 1951) (entered into force for U.S. 23 Feb. 1989).

${ }_{65}$ Naomi Roht-Arriaza, State Responsibility to Investigate and Prosecute Grave Human Rights Violations in International Law, 78 CALIFORNIA L. REV. 449 (1990).

${ }^{66}$ Universal Declaration of Human Rights, adopted 10 Dec. 1948, G.A. Res. 217A (III), U.N. GAOR, 3d Sess, U.N. Doc. A/RES/3/217A (1948).

${ }^{67}$ SAmuel Moyn, The Last UtOpia: Human Rights In History 82 (2010).

${ }^{68}$ International Convention on the Elimination of All Forms of Racial Discrimination, adopted 21 Dec. 1965, G.A. Res. 2106 (XX), U.N. GAOR, 20th Sess., U.N. Doc. A/RES/20/2106 (1965), 660 U.N.T.S. 195 (entered into force 4 January 1969) (entered into force for U.S. 21 Oct. 1994) [hereinafter ICERD].

${ }^{69}$ Id. art. 4.
} 
the time and its adoption was criticized by a number of states. ${ }^{70}$ It was then the Convention against Torture and Other Cruel, Inhuman or Degrading Treatment or Punishment, adopted by the UN General Assembly (UNGA) in 1984, that marked the turn to criminal law in the UN human rights project. ${ }^{71}$ This convention is one of the first universal human rights treaties to set forth a duty for states to provide for effective criminal repression of serious wrongdoings by universal jurisdiction. ${ }^{72}$ Article 4(1) obliges states to "ensure that all acts of torture are offences under [their] criminal law.",73 Moreover, pursuant to Articles 5-7, state parties shall submit any case involving acts of torture to their competent authorities for the purpose of prosecution, without any regard for the place of the commission of the acts, if suspects are in their territory and are not extradited. These provisions lay down the legal principle of aut dedere aut judicare, whose purpose is to ensure that no safe haven from criminal prosecution is granted to perpetrators of torture. ${ }^{74}$ Furthermore, the duty to institute criminal proceedings against alleged torturers appears to preclude state parties from passing amnesty laws that hinder such prosecutions. ${ }^{75}$

The Torture Convention represents a watershed in the promotion of criminal law for the

70 Steven Malby, Criminal TheOry and International Human Rights 71-73 (2020).

${ }^{71}$ Convention Against Torture and Other Cruel, Inhuman or Degrading Treatment or Punishment, adopted 10 Dec. 1984 , G.A. Res. 39/46, U.N. GAOR, 39th Sess., U.N. Doc. A/39/51 (1985), 1465 U.N.T.S. 85 (entered into force 26 June 1987) [hereinafter CAT]; Malcolm D. Evans, The Criminalisation of Torture as a Part of the Human Right Framework, 2 CRIMEN (V) 136, 136 (2014). One can consider the International Convention on the Suppression and Punishment of the Crime of Apartheid, U.N. Doc.A/RES/3068(XXVIII) (1973) as a previous case of human rights treaty that heavily relies on criminal-law enforcement. However, this convention "appears to have been adopted more for political reasons rather than to create a legal framework for the prosecution of perpetrators." (Carla Edelenbos, Human Rights Violations: A Duty to Prosecute?, 7 LEIDEN J. INT'L L. 5, 7 (1994)).

72 Manfred Nowak, Moritz Birk \& Giuliana Monina, Introduction, in THE UnITED NATIOns CONVENTION AgAINST Torture And its Optional Protocol: A Commentary 1, 3-4 (Manfred Nowak, Moritz Birk, \& Giuliana Monina eds., 2nd ed. 2019); Nigel Rodley \& Matt Pollard, Criminalisation of Torture: State Obligations Under the United Nations Convention Against Torture and Other Cruel, Inhuman or Degrading Treatment or Punishment, 2 EuR. HUM. RTS L. REV. 115 (2006). Universal jurisdiction means the authority of a state to exercise its criminal jurisdiction over crimes regardless of the place of commission, the link of nationality or any other factual relationship linking the suspect to the acting state.

${ }^{73}$ CAT, supra note 71, art. 4(1).

${ }^{74}$ M. Cherif Bassiouni \& Edward M. Wise, Aut Dedere Aut Judicare: The Duty to Extradite or Prosecute IN INTERNATIONAL LAW (1995).

${ }^{75}$ Diane F. Orentlicher, Settling Accounts: The Duty to Prosecute Human Rights Violations of a Prior Regime, 100 YALE L. J. 2537, 2567 (1991); Michael P. Scharf, The Letter of the Law: The Scope of the International Legal Obligation to Prosecute Human Rights Crimes, 59 L. \& CONTEMP. PROBS. 41, 46-47 (1996). 
purpose of human rights protection. ${ }^{76}$ The principle of aut dedere aut judicare had previously been deployed almost exclusively outside the human rights framework. The Swedish Government, which proposed it, used as a model the corresponding provisions in a number of treaties against various forms of terrorism. ${ }^{77}$ The Torture Convention is also innovative with regard to the outcome that criminal proceedings for torture should have. Pursuant to Article 4(2), states are required to punish torture "by appropriate penalties which take into account their grave nature." ${ }^{\text {"78 }}$ This implies a severe sentence. ${ }^{79}$ No previous human rights treaty had yet made mandatory that human rights violations be punished with harsh criminal penalties. Also, in this case, the drafting parties took enforcement provisions from anti-terrorist conventions and applied them to the Torture Convention, a human rights treaty. ${ }^{80}$ Although we might not find it strange, this drafting seemed unusual at the time. As Malcolm Evans has noted, many states, that had no difficulty in accepting jurisdictional and extradition obligations in the context of anti-terrorist conventions, nevertheless did not accept them easily in a convention that they perceived to be about human rights. ${ }^{81}$

Several examples following the adoption of the Torture Convention reflect an increasing concern on the part of the UN to make prosecution and punishment of gross human rights violations legally obligatory. ${ }^{82}$ In 1985 , the UNGA unanimously adopted the UN Victims' Declaration. This instrument calls on states "to enact and enforce legislation proscribing acts that

\footnotetext{
${ }^{76}$ Evans, supra note 71 , at 137.

77 Convention for the Suppression of Unlawful Seizure of Aircraft, 860 UNTS 105 (1970); Convention for the Suppression of Unlawful Acts against the Safety of Civil Aviation, 974 U.N.T.S. 177 (1971); Convention on the Prevention and Punishment of Crimes Against Internationally Protected Persons, Including Diplomatic Agents, 1035 U.N.T.S. 167 (1973); International Convention against the Taking of Hostages, 1316 U.N.T.S. 205 (1979); see also J. Herman Burgers \& Hans Danelius, The United NATIONS CONVENTiOn AgAinst TORTURE: A HANDBOOK ON the Convention Against Torture and Other Cruel, InHuman, or Degrading Treatment or Punishment 35 (1988).

${ }^{78}$ CAT, supra note 71 , art. 4(2).

${ }^{79}$ Nóra Katona, Article 4: Obligation to Criminalize Torture, in The United NATIOns Convention AgAinst TORTURE, supra note 72 , at $176,186-87$.

${ }^{80}$ Burgers \& DANELIUS, supra note 77, at 130.

${ }^{81}$ Evans, supra note 71, at 137.

82 Roht-Arriaza, State Responsibility to Investigate and Prosecute Grave Human Rights Violations in International Law, supra note 65, at 499 .
} 
violate internationally recognized norms relating to human rights, corporate conduct and other abuses of power" and "to establish and strengthen the means of detecting, prosecuting and sentencing those guilty of crimes." ${ }^{\prime 3}$ In 1989, the UN Economic and Social Council included obligations to investigate, prosecute, and punish human rights violations among the Principles on the Effective Prevention and Investigation of Extra-legal, Arbitrary and Summary Executions. ${ }^{84}$ The duty to resort to criminal law measures against grave human rights abuses also appears in a number of international instruments drafted since the late 1980s and modelled on or inspired by the Torture Convention. These include the Inter-American Convention to Prevent and Punish Torture ${ }^{85}$ the Basic Principles on the Use of Force and Firearms by Law Enforcement Officials, adopted by the Eighth UN Congress on the Prevention of Crime and the Treatment of Offenders in $1990 ;^{86}$ the Declaration on the Protection of All Persons From Enforced or Involuntary Disappearances, adopted by the UNGA in $1992 ;^{87}$ the two Optional Protocols to the Convention on the Rights of the Child, respectively on the Sale of Children, Child Prostitution and Child Pornography (2000) and on the Involvement of Children in Armed Conflict (2000), ${ }^{88}$ and the International Convention for the Protection of All Persons from Enforced Disappearances (2006). ${ }^{89}$

In the same years, criminal law emerged as a necessary instrument of any UN human rights policy seeking to promote accountability and combat impunity. For instance, in 1993 the Vienna Declaration and Program of Action, arising from the UN World Conference on Human Rights,

\footnotetext{
${ }^{83}$ Res. 40/34, supra note 22, 4(c)-(d).

84 UN Economic and Social Council, Principles on the Effective Prevention and Investigation of Extra-legal, Arbitrary and Summary Executions, Res.1989/65 (1989).

85 Inter-American Convention to Prevent and Punish Torture, OASTS 67 (1985).

${ }^{86}$ Eighth UN Congress on the Prevention of Crime and the Treatment of Offenders, Basic Principles on the Use of Force and Firearms by Law Enforcement Officials (1990).

${ }^{87}$ Declaration on the Protection of All Persons from Enforced Disappearance, adopted 18 Dec. 1992, G.A. Res. 47/133, U.N. GAOR, 47th Sess., U.N. Doc. A/RES/47/133 (1992).

88 Optional Protocol to the Convention on the Rights of the Child on the Sale of Children, Child Prostitution and Child Pornography, 2171 U.N.T.S. 247 (2000); Optional Protocol to the Convention on the Rights of the Child on the Involvement of Children in Armed Conflict, 2173 U.N.T.S. 222 (2000).

${ }^{89}$ International Convention for the Protection of All Persons from Enforced Disappearances, 2716 U.N.T.S. 3 (2006).
} 
urged states to "abrogate legislation leading to impunity for those responsible for grave violations of human rights such as torture and prosecute such violations, thereby providing a firm basis for the rule of law." 90 The UN Sub-Commission on Prevention of Discrimination and Protection of Minorities has also reiterated the same issue since 1991, when it requested Louis Joinet and El Hadji Guissé to undertake a study on the impunity of perpetrators of human rights abuses. ${ }^{91}$ The study was subsequently split in two parts and produced two reports concerning violations of civil and political rights and breaches of economic, social, and cultural rights, respectively. ${ }^{92}$ Joinet's report, in particular, included a Set of Principles for the Protection and Promotion of Human Rights through Action to Combat Impunity (Joinet's Principles), whose content was taken "note of" by the UN Commission on Human Rights in $1998 .^{93}$

In 2003, the UN Secretary General invited Diane Orentlicher to update the Joinet's Principles. ${ }^{94}$ In 2005, Orentlicher submitted the Updated Set of Principles for the Protection and Promotion of Human Rights through Action to Combat Impunity (UN Principles to Combat Impunity), which was endorsed by the UN Commission on Human Rights. ${ }^{95}$ By considering impunity as hindering the implementation of human rights and calling for the prosecution and punishment of human rights abuses, ${ }^{96}$ these principles have served as an important point of reference on debates on criminal accountability for human rights violations within and beyond the

\footnotetext{
90 Vienna Declaration and Programme of Action, adopted 25 June 1993, U.N. GAOR, World Conf. on Hum. Rts., 48th Sess., 22d plen. mtg., U.N. Doc. A/CONF.157/23 (1993), reprinted in 32 I.L.M. 1661 (1993).

${ }^{91}$ Frank Haldemann \& Thomas Unger, Introduction, in THE United NATIONS PRINCIPLES TO COMBAT IMPUNITY: A COMmentary 4 (Frank Haldemann \& Thomas Unger eds., First edition ed. 2018).

${ }^{2}$ UN Commission on Human Rights, Question of the Impunity of Perpetrators of Human Rights Violations (Civil and Political), U.N. Doc. E/CN4/Sub2/1997/20/Rev1 (1997); UN Commission on Human Rights, Final Report on the Question of the Impunity of Perpetrators of Human Rights Violations (Economic, Social and Cultural Rights), U.N. Doc. E/CN4/Sub2/1997/8 (1997).

93 UN Commission on Human Rights, Impunity, Res 1998/53, ESCOR Supp. (No 3) at 175, U.N. Doc. E/CN4/1998/53 (1998).

94 UN Commission on Human Rights, Promotion and Protection of Human Rights_Impunity, Note by the Secretary-General, U.N. Doc. E/CN4/2004/88 (2004).

${ }^{95}$ UN Commission on Human Rights, Updated Set of Principles for the Protection and Promotion of Human Rights through Action to Combat Impunity, U.N. Doc. E/CN4/2005/102/ADD1 (2005).

${ }^{96}$ Id. at 1, 19, 21, 22, 24.
} 
UN. ${ }^{97}$ For instance, upon the influence of the UN Principles to Combat Impunity, in 2009 the Council of Europe's Parliamentary Assembly approved a recommendation on "The state of human rights in Europe: the need to eradicate impunity;"'98 while in 2011 the Council of Europe's Committee of Ministers adopted a series of guidelines titled Eradicating Impunity for Serious Human Rights Violations. ${ }^{99}$ The UN Principles to Combat Impunity emerged in parallel with another key UN document dedicated to state obligations, namely the Basic Principles on the Right to a Remedy and Reparation for Victims of Gross Violations of International Human Rights Law and Serious Violations of International Humanitarian Law (the Van Boven/Bassiouni Principles). ${ }^{100}$ Adopted by the UNGA in 2005, this instrument includes an obligation on states to punish human rights violations constituting international crimes, along with provisions on victims' rights. ${ }^{101}$

In brief, in the last forty years, a wide array of activities of the UN and other intergovernmental organizations have promoted the view that criminal law plays a necessary part in protecting human rights. ${ }^{102}$ Following the adoption of the Torture Convention, there has been growing tendency to urge states to criminalize, prosecute, and punish serious human rights violations.

\section{TRANSITIONAL CRIMINAL JUSTICE}

\footnotetext{
${ }^{97}$ Haldemann \& Unger, supra note 91, at 15, 19; Naomi Roht-Arriaza, Principle 1. General Obligations of States to Take Effective Action to Combat Impunity, THE UniTED NATIONS PRINCIPLES TO COMBAT IMPUNITY, supra note 91, at 47, 51.

${ }_{98}$ Council of Europe (CoE), Recommendation of the Parliamentary Assembly-State of Human Rights in Europe: The Need to Eradicate Impunity, Rec. 1876 (2009).

${ }_{99}$ CoE, Eradicating Impunity for Serious Human Rights Violations (2011).

100 UN General Assembly, Basic Principles and Guidelines on the Right to a Remedy and Reparation for Victims of Gross Violations of International Human Rights Law and Serious Violations of International Humanitarian Law, Res 60/147, U.N. Doc. A/RES/60/147 (2006), Annex (2005).

$101 \mathrm{Id}$. at 4.

102 Orentlicher, supra note 75 , at 2583.
} 
The use of human rights in encouraging increased penality is also visible in the developments of transitional justice. Transitional justice has been defined as "the conception of justice associated with periods of political change, characterized by legal responses to confront the wrongdoings of repressive predecessor regimes." ${ }^{103}$ By its very definition, it is concerned with accountability for human rights abuses of the past. Amongst many forms of accountability, criminal prosecution frequently figures as "the preferred choice." 104 Transitional justice is a field of scholarship, policy, and practice that began to emerge in the late $1980 \mathrm{~s} .{ }^{105}$ It is the result of a debate among human rights activists on how to deal with past violence in countries where democratic governments supplanted long-rooted dictatorships, ${ }^{106}$ following the "third wave of democratization" between 1974 and $1990 .{ }^{107}$ An important contribution comes from the case of Argentina, where, with the end of the military dictatorship in 1983, the newly elected Raul Alfonsín tried to prosecute the junta’s top leaders. ${ }^{108}$ A commission of inquiry, convened by Alfonsín’s government, published a report on “disappearances" by state security forces. The judiciary conducted a series of trials. However, between 1986 and 1987, under pressure from the military, the government decided to terminate the prosecutions. A subsequent government passed an amnesty law for those sentenced to prison. Alfonsín's project failed but it paved the way for a new debate among activists, scholars and policymakers concerned with human rights and "transitions to democracy." A series of conferences

103 Ruti Teitel, Transitional Justice Genealogy, 16 HARV. HuM. RTS. J. 69, 69 (2003).

104 John Dugard, Dealing With Crimes of a Past Regime. Is Amnesty Still an Option?, 12 LEIDEN J. INT'L L. 1001, 1001 (1999); Francesca Lessa \& Leigh A. Payne, Introduction, in AMNESTY IN THE AGE OF HumAN RigHTS AcCOUNTABILITY: Comparative and International Perspectives 1, 5 (Francesca Lessa \& Leigh A. Payne eds., 2012). See also Miriam J. Aukerman, Extraordinary Evil, Ordinary Crime: A Framework for Understanding Transitional Justice, 15 HARV. HUM. RTS. J. 39, 40 (2002).

105 Paige Arthur, How “Transitions” Reshaped Human Rights: A Conceptual History of Transitional Justice, 31 HUM. RTS. Q. 321 (2009); Padraig McAuliffe, From Molehills to Mountains (and Myths?): A Critical History of Transnational Justice Advocacy, 22 FinNish Y.B InT’L L. 85 (2011); MARCos ZuninO, Justice Framed: A GeneAlogy of Transitional JustiCE 3 (2019). For Teitel, transitional justice starts with the Nuremberg Trials, although none of those involved would have described it as such. See Teitel, supra note 103.

106 Arthur, supra note 105, at 324.

107 Samuel P. Huntington, The Third Wave: Democratization in the Late Twentieth Century (1991).

108 Carlos S. Nino, Radical Evil on Trial (1996); Anne Marie Latcham, Duty to Punish: International Law and the Human Rights Policy of Argentina, 7 BOSTON UNIV. INT’L L. J. 355 (1989). 
between the late 1980s and early 1990s marked the birth of the field of transitional justice. ${ }^{109}$

Transitional justice represents a further move from "naming-and-shaming" and toward criminal accountability among human rights activists. ${ }^{110}$ Until the mid-1980s, in addressing repressive governments, human rights organizations had rarely called for criminal accountability, since the power to conduct criminal trials was in the hands of the same leaders that were denounced. ${ }^{111}$ With the end of the Cold War and the collapse of oppressive regimes in Latin America, Africa, Asia, and Eastern Europe, a new attitude toward criminal law emerged, as no longer a source of abuses but as a way to remedy them. Once accountability for past wrongdoings became possible, human rights organizations did not hesitate to choose as a model the criminal legal system already in place for ordinary crimes. The recourse to criminal law was not debated but perceived as the obvious avenue for human rights enforcement. ${ }^{112}$

Given the deficiencies of most domestic legal systems involved in transitions, the source of an obligation to conduct criminal proceedings was looked for from within international law. ${ }^{113}$ Orentlicher wrote that international human rights law required the prosecution and punishment of especially atrocious crimes. ${ }^{114}$ Carlos Nino responded that Orentlicher's analysis failed to account for the complex factual context that successor governments may confront in deciding whether to conduct trials for human rights violations. ${ }^{115}$ Nino suggested that the urge for prosecution should be

\footnotetext{
109 Arthur, supra note 105, at 324-25; ZUNINO, supra note 105, at 70-71.

110 Arthur, supra note 105, at 334.

111 Karen Engle, A Genealogy of the Criminal Turn in Human Rights, in ANTI-IMPUNITY AND THE HuMAN RIGHTS AGENDA, supra note 4, at 15, 18-21.

112 Kathryn Sikkink, The Justice Cascade: How Human Rights Prosecutions Are Changing World POLITICS 20 (2011).

113 Roht-Arriaza, State Responsibility to Investigate and Prosecute Grave Human Rights Violations in International Law, supra note 65.

114 Orentlicher, supra note 75.

115 Carlos S. Nino, The Duty to Punish Past Abuses of Human Rights Put into Context: The Case of Argentina, 100 YALE L. J. 2619 (1991).
} 
counterbalanced with the aim of preserving the democratic system. ${ }^{116}$ Thus, in the early 1990 s, the discussion revolved around the tension between punishment and political stability, between the demands of justice and the needs of a sustainable peace. ${ }^{117}$ In the words of José Zalaquett, "measures which are straightforward from the standpoint of human rights norms could have undesired political implications." 118 Even in this phase of transitional justice, the compatibility of criminal law with human rights was taken for granted. The discussion did not concern whether human rights required criminal accountability, but how much accountability and what compromises could be accepted during delicate political transformations. ${ }^{119}$ A number of countries recognized the dilemma between peace and justice and decided to forego criminal proceedings in favor of other methods of accountability. ${ }^{120}$ The South African experience is a prominent example. In 1995 , South Africa established a Truth and Reconciliation Commission (TRC), whose purpose was, among others, to grant amnesty and extinguish criminal and civil liability for those who disclosed their wrongdoings during the apartheid period, if associated with a political objective. ${ }^{121}$ Called to decide upon the constitutionality of the TRC's provisions, the South African Constitutional Court did not deny that perpetrators deserved punishment, but it saw amnesty as crucial to the aim of reconciliation. $^{122}$

Over time, however, most human rights NGOs, courts, and scholars came to dismiss the tension between peace and justice, and criminal justice started being seen as complementary and no

\footnotetext{
$116 I d$.

117 Kieran McEvoy \& Louise Mallinder, Amnesties in Transition: Punishment, Restoration, and the Governance of Mercy, 39 J. L. \& SOC’Y 410, 412 (2012).

118 José Zalaquett, Confronting Human Rights Violations Committed by Former Governments: Principles Applicable and Political Constraints, in STATE CRIMES: PUNISHMENT OR PARDON 23, 24 (Aspen Institute ed., 1989).

119 Ellen L. Lutz \& Caitlin Reiger, Introduction, in Prosecuting HeADs OF STATE 1-24, 4 (Ellen L. Lutz \& Caitlin Reiger eds., 2009).

120 Teitel, supra note 103, at 77.

121 SA Promotion of National Unity and Reconciliation Act, art. 3(1)(b) (1995).

122 South African Constitutional Court, Azanian Peoples Organization (AZAPO) and Others v. President of the Rep. of S. Afr., 4 SA 672 (1996). Critics of the South African model have also shown how the TRC still relied on "antiimpunity" logics, see Mahmood Mamdani, The Politics of Memory: Truth, Healing and Social Justice, in THE POLITICS OF MEMOrY: Truth, Healing AND Social Justice 176 (Ifi Amadiume \& Abdullah An-Na'im eds., 2000).
} 
longer in opposition to peace. ${ }^{123}$ The atrocities that occurred in the Balkans prompted the UN Security Council (UNSC) to establish the International Criminal Tribunal for the former Yugoslavia (ICTY). ${ }^{124}$ The tribunal was supposed not merely to try the worst offenders, but also to contribute to reconciliation, create a historical record, and deter ongoing atrocities. ${ }^{125}$ Its mandate was "to impose justice before peace, and as a means to achieve peace." 126 The ICTY added an international dimension to transitional justice, leading the way for the establishment of other international institutions, including the International Criminal Tribunal for Rwanda (ICTR) ${ }^{127}$ and the ICC. ${ }^{128}$ The demand for more judicialization and institutionalization at the international level is to be seen as an attempt to relieve the tension between legal and moral obligations to punish and the need for political stability. International bodies are deemed to provide a neutral and apolitical response to chaotic local politics. ${ }^{129}$ They administer retributive justice in external settings (e.g. in The Hague) and in a supposedly impartial manner, through universal rules and procedure. ${ }^{130}$ They are also opposed to domestic political powers, seen as incapable of managing complex social problems, including the protection of human rights. ${ }^{131}$

The turn of the century marked what has been called the "justice cascade" 132 or the "revolution in accountability": ${ }^{133}$ individual criminal accountability by reference to human rights gained momentum and became an integral part of all international, regional, and national projects of

\footnotetext{
${ }^{123}$ Engle, supra note 111 at 28.

124 UN Security Council, UNSC Res. 827, U.N. Doc. S/RES/827 (1993).

125 Naomi Roht-Arriaza, The new Landscape of Transitional Justice, in TransitionAL JUSTICE IN THE TwENTY-FIRST Century: Beyond Truth Versus Justice 1, 6 (Naomi Roht-Arriaza \& Javier Mariezcurrena eds., 2006).

126 Ruti Teitel, Globalizing Transitional JustiCE: CONTEMPORARY ESSAYS 82 (2014).

127 UN Security Council, UNSC Res 955, U.N. Doc. S/RES/955 (1994).

128 Rome Statute, supra note 25.

${ }^{129}$ Karen Engle, Zinaida Miller \& Dennis M. Davis, Introduction, in ANTI-IMPUNITY AND THE HuMAN RIGHTS AGENDA, supra note 4, at 1, 5-6.

130 Zinaida Miller, Anti-Impunity Politics in Post-Genocide Rwanda, in ANTI-IMPUNITY AND THE HuMAN RigHTS AGENDA, supra note 4 , at 149, 150-51.

131 Id. at 159-62.

132 SIKKINK, supra note 112.

133 Chandra Lekha Sriram, Revolutions in Accountability: New Approaches to Past Abuses, 19 Am. UNIV. INT’L L. REV. 301 (2003).
} 
justice. The general perception was that a "new age of accountability" was replacing an "old era of impunity." 134 The dilemma between peace and justice became less relevant. ${ }^{135}$ Criminal justice had to be done, not only to hold perpetrators accountable, but also to report the truth and vindicate the victims. ${ }^{136}$ Two events in 1998 have been described as the trigger moments: the establishment of the ICC and the arrest of Chilean general and dictator Augusto Pinochet in London on a Spanish extradition warrant for torture and other human rights violations. ${ }^{137}$ For Naomi Roht-Arriaza, the latter event represented the most significant move toward a transnational fight for accountability, whereby leaders who committed gross abuses could no longer escape from prosecution and punishment for their actions. ${ }^{138}$ The Pinochet case gave practical effect to the Torture Convention and revitalized the principle of universal jurisdiction, namely the idea that courts of one country can hold foreign perpetrators criminally accountable for wrongdoings committed abroad. In recent years, human rights obligations have been invoked in the prosecution and punishment of various heads of state responsible for mass abuses, including former Peruvian president Alberto Fujimori, former Uruguayan president Juan María Bordaberry, and former Panamanian military dictator Manuel Noriega. ${ }^{139}$ Despite criticism, ${ }^{140}$ universal jurisdiction has gained increased relevance as a way to intervene and prevent impunity for human rights abuses. ${ }^{141}$

A recent debate involves the question of the legitimacy of amnesty laws under international

134 Ban Ki-moon, At ICC Review Conference, Ban Declares end to "Era of Impunity," UN NEws (2010), https://news.un.org/en/story/2010/05/340252.

135 Lisa J. Laplante, Outlawing Amnesty: The Return of Criminal Justice in Transitional Justice Schemes, 49 VA. J. INT’L L. 915,920 (2009).

136 Roht-Arriaza, The new Landscape of Transitional Justice, supra note 125, at 1.

${ }^{137}$ Kathryn Sikkink, The Age of Accountability: The Global Rise of Individual Criminal Accountability, in AMNESTY IN THE AGE OF HUMAN RigHTS ACCOUNTABILITY, supra note 104, at 19, 33, 37.

138 NaOmi Roht-Arriaza, The Pinochet EfFECt: Transnational Justice in the Age Of Human Rights (2005).

139 Lessa \& Payne, supra note 104, at 1-2.

${ }^{140}$ Luc Reydams, The Rise and Fall of Universal Jurisdiction, in ROUTLEDGE HANDBOOK OF INTERNATIONAL CRIMINAL LAW 337 (William A. Schabas \& Nadia Bernaz eds., 2011).

141 Juan E. Méndez, Foreword, in AmneSTY IN THE AGE OF Human RIGHTS ACCOUNTABILITY, supra note 104, xvii-xxix, xxi. 
law and their persistence "in the age of human rights accountability." ${ }^{142}$ In an earlier era, human rights advocates had often pleaded for amnesty for political prisoners. ${ }^{143}$ Conversely, today, amnesties are viewed with disfavor by those who believe that perpetrators of atrocities should be held criminally responsible for their acts. ${ }^{144}$ While, for a minority of authors, amnesties can still have a place in the international system as an effective tool for social reconciliation, ${ }^{145}$ most human rights NGOs, courts, scholars, and policymakers see amnesty laws as contrary to international law when they restrict duties to prosecute and punish mass abuses. ${ }^{146}$ Even the South Africa TRC experience is no longer regarded as a legitimate model. Juan Méndez wrote that, as a result of "the rapid evolution of international law," today "the South African-style 'conditional amnesty" would be unacceptable “if it covered war crimes, crimes against humanity (including disappearances), or torture."147

Nowadays, even though countries continue adopting amnesties, conducting sham trials, or undertaking selective prosecutions, ${ }^{148}$ legal doctrine and legal institutions at the international, regional, and local levels increasingly consider criminal accountability as the only legitimate option for addressing past atrocities. The duty to employ criminal law, justified through human rights law

\footnotetext{
142 Lessa \& Payne, supra note 104, at 4. Amnesties can be defined as "legal measures adopted by states that have the effect of prospectively barring criminal prosecution against certain individuals accused of committing human rights violations" (Id.).

143 Engle, supra note 111, at 17.

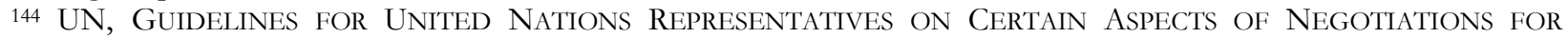
CONFLICT RESOLUTION 12 (1999), https://legal.un.org/docs/?path=../unjuridicalyearbook/pdfs/english/by_volume/2006/chpVI.pdf\&lang=EF. This is an internal document that has guided UN mediators in situations of transitional justice since 1999. These guidelines formed the basis for the United Nations formal rejection of amnesties for serious human rights violations.

145 Jack Snyder \& Leslie Vinjamuri, Trials and Errors: Principle and Pragmatism in Strategies of International Justice, 28 INT'L SEC. 5 (2004); William W. Burke-White, Reframing Impunity: Applying Liberal International Law Theory to an Analysis of Amnesty Legislation, 42 HARV. INT'L L. J. 467 (2001); Mark Freeman \& Max Pensky, The Amnesty Controversy in International Law, in AMNESTY IN THE AGE OF HuMAN RigHTS ACCOUNTABILITY, supra note 104, at 42.

146 Méndez, supra note 141; Dugard, supra note 104.

147 Méndez, supra note 141, xxiii.

148 Louise Mallinder, Amnesties' Challenge to the Global Accountability Norm? Interpreting Regional and International Trends in Amnesty Enactment, in AMNESTY IN THE AGE OF HuMAN RIGHTS ACCOUNTABILITY, supra note 104, at 69.
} 
and language, has become the new norm. ${ }^{149}$ Other non-punitive measures (truth commissions, fact finding inquiries, reparation programs, or limited amnesties) may still be used as pragmatic compromises, provided that they do not block criminal proceedings or jeopardize the call for criminal accountability. ${ }^{150}$ While a number of scholars and activists acknowledge the need of forms of structural accountability beyond prosecutions, they nonetheless keep placing the emphasis on criminal justice. ${ }^{151}$ There is a general sense that conducting more criminal trials in the aftermath of atrocities is beneficial for democracy and the rule of law, inasmuch as trials adhere to due process principles. ${ }^{152}$ Even those governments which otherwise would not have an interest in prosecution, are pushed toward criminal proceedings for past atrocities. In so doing, they incorporate the fight against impunity into their efforts to gain legitimacy and consolidate authority. ${ }^{153}$

The language of human rights is crucial in the enduring relevance of criminal-law mechanisms in transitional justice projects. The global crisis of the radical Left at the end of the 1970s not only marked an ideological shift from political ideology and toward human rights, ${ }^{154}$ but also an abandonment of projects of radical social justice in favor of legal, institutional reforms aimed at defending the rights of individuals. ${ }^{155}$ State violence has been read in terms of human rights violations that require legalistic responses (especially prosecution and punishment of past leaders) rather than as an expression of class domination that mandates large-scale redistribution or a

\footnotetext{
149 Payne, supra note 2, at 467; SIKKINK, supra note 112, at 11. For a critique of the effectiveness of the accountability norm, see Padraig McAuliffe, The Roots of Transitional Accountability: Interrogating the "Justice Cascade," 9 INT’L J. L. IN CONTEXT 106 (2013).

150 Payne, supra note 2, at 454; Tricia D. Olsen, Leigh A. Payne \& Andrew G. Reiter, Conclusion: Amnesty in the Age of Accountability, in AMNESTY IN THE AGE OF HuMAN RigHTS ACCOUNTABILITY, supra note 104, at 336, $346-47$.

151 Sedacca, supra note 4.

152 SIKKINK, supra note 112, at 26-27; Hunjoon Kim \& Kathryn Sikkink, Explaining the Deterrence Effect of Human Rights Prosecutions for Transitional Countries, 54 INT'L STUD. Q. 939, 953 (2010); for a different view, see Snyder \& Vinjamuri, supra note 145.

${ }_{153}$ Miller, supra note 130, at 150-52; Leslie Vinjamuri \& Jack Snyder, Law and Politics in Transitional Justice, 18 ANN. REV. POL. SCI. 303 (2015).

${ }^{154}$ MOYN, supra note 67, at 213.

155 Arthur, supra note 105, at 339-40.
} 
profound transformation of society. ${ }^{156}$ Legalistic conceptions of rights and justice also dominate the field of transitional justice. ${ }^{157}$ Human rights are framed as legal standards that prioritize retributive notions of justice over political calls for forgiveness and reconciliation. ${ }^{158}$ Conversely, the absence of punitive measures is often regarded as a failure to uphold legal obligations which, in turn, paves the way to further violence. ${ }^{159}$ This approach has had two consequences. First, the prosecution of massive and systemic human rights abuses has conferred a legitimacy on criminal law that it could have never gained in addressing common crimes. ${ }^{160}$ Second, as Karen Engle has noted, "the correspondence between criminal prosecution and human rights has become so ingrained that expressing opposition to any particular international prosecution is sometimes seen as anti-human rights." 161

\section{PROMOTING HUMAN RIGHTS THROUGH INTERNATIONAL CRIMINAL LAW}

The history of international criminal law is often narrated as a triumphant story of human rights protection. ${ }^{162}$ The story begins with the failure of the international community to respond to mass violence for centuries. Then, for the first time with Nuremberg and Tokyo—-the story goes—we succeeded to impose individual criminal responsibility for atrocities. Finally, after fifty years of impunity during the Cold War, the story culminates with the establishment of the ad hoc tribunals

\footnotetext{
${ }^{156}$ Id. at 347; Robert Meister, After Evil: A Politics OF Human Rights 1 (2011).

${ }^{157}$ Kieran McEvoy, Beyond Legalism: Towards a Thicker Understanding of Transitional Justice, 34 J. L. \& SOC’Y 411 (2007).

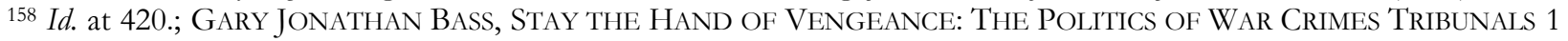
(2000).

159 JOHn Borneman, Settling ACCOUnts: Violence, Justice, And ACCOUntability in Postsocialist Europe (1997).

160 Peer Stolle \& Tobias Singelnstein, On the Aims and Actual Consequences of International Prosecution of Human Rights Crimes, in International Prosecution of Human Rights Crimes 37, 49 (Wolfgang Kaleck et al. eds., 2007).

${ }^{161}$ Engle, supra note 111, at 42.

162 See, e.g., The International Criminal Court: The Making of the Rome Statute Issues, Negotiations, RESUlTS (Roy S. Lee ed., 1999).
} 
and the ICC as the "stupendous achievement in the world community" for the protection of individual rights. ${ }^{163}$ However, international criminal law has not always been concerned with human rights. As Samuel Moyn observes, the Nuremberg Trials were primarily focused on aggression, while the Holocaust and other atrocities remained marginal. ${ }^{164}$ It was only in the 1990 s that international criminal adjudication was reinvented as part of the human rights project and shifted its attention to accountability for human rights violations. ${ }^{165}$

Notwithstanding the above, the first international criminal tribunals after the Cold-War were not created for breaches of human rights law, but primarily for war-time atrocities. In 1993, the UNSC established the ICTY "for the prosecution of persons responsible for serious violations of international humanitarian law committed in the territory of the former Yugoslavia."166 The ICTR was created in 1994 "for the sole purpose of prosecuting persons responsible for genocide and other serious violations of international humanitarian law committed in the territory of Rwanda."167 Yet, albeit primarily violations of the Geneva and Genocide Conventions, the mass atrocities committed in the Balkans and Central East Africa were also read in terms of human rights violations due to their universal moral repugnance. ${ }^{168}$ With the ICTY and the ICTR, the distinction between humanitarian law and human rights became increasingly blurred. ${ }^{169}$ Human rights law started being applied in armed conflicts and war crime trials became a new means to promote human rights. ${ }^{170}$

\footnotetext{
163 Antonio Cassese, Reflections on International Criminal Justice, 9 J. INT’L CRIM. JUST. 271, 272 (2011).

164 Samuel Moyn, From Aggression to Atrocity: Rethinking the History of International Criminal Law, in THE OXFORD HANDBOOK OF INTERNATIONAL CRIMINAL LAW 341 (Kevin Jon Heller et al. eds., 2020).

165 Id.; Frédéric Mégret, International Criminal Justice as a Peace Project, 29 EUR. J. INT’L L. 835 (2018).

166 UN Security Council, UNSC Res. 808, U.N.Doc. S/RES/808 (1993).

${ }^{167}$ UNSC Res 955, supra note 127. Along with the two tribunals, the first UN prison was established in The Hague.

168 Similarly, see Kirsten Ainley, Responsibility for Atrocity: Individual Criminal Agency and the International Criminal Court, in Evil, Law And the State: Perspectives on State Power and Violence 143, 144 (John T. Parry ed., 2006).

169 Theodor Meron, Human Rights Law Marches into New Territory: The Enforcement of International Human Rights in International Criminal Tribunals (Marek Nowicki Memorial Lecture), in THE MAKING OF INTERNATIONAL CRIMINAL JUSTICE: THE VIEW FROM THE BENCH: SELECTED SPEECHES 181 (2011).

170 Juan E. Méndez, International Human Rights Law, International Humanitarian Law and International Criminal Law and Procedure New Relationships, in InTERnATIOnAl CRIMES, PEACE, AND Human Rights: THE ROLE OF THE INTERNATIONAL CRIMINAL COURT 65, 68 (Dinah Shelton ed., 2000).
} 
Because the Geneva Conventions laid down criminal accountability for grave breaches of humanitarian law, its application to other egregious abuses that appeared as compelling. ${ }^{171}$

The institutionalization of the ad hoc tribunals reinvigorated a long-standing interest in creating a permanent international criminal court. ${ }^{172}$ Not only would this court prosecute violations of humanitarian law in armed conflicts, but also gross human rights abuses occurred in peacetime. ${ }^{173}$ A decisive impetus to the creation of the ICC came from global civil society. In 1995, a group of human rights NGOs created the Coalition for an International Criminal Court (CICC). ${ }^{174}$ In the following years, this advocacy network undertook a decisive activity of lobbying with state representatives, produced expert documents, organized conferences, distributed information, raised funds, and organized public demonstrations. ${ }^{175}$ A great push toward institution-building came also from women's human rights activists who saw the ICC as an opportunity to expand the criminalization of sexual violence both in armed conflict and in peacetime. ${ }^{176}$ The Rome Statute was eventually adopted on 17 July 1998 and entered into force on 1 July 2002. ${ }^{177}$ The ICC was applauded as "a gift of hope to future generations, and a giant step forward in the march towards universal human rights and the rule of law." ${ }^{178}$ Since then, the Court has been presented as the cornerstone of a broad human rights agenda, namely the "fight against impunity." This emerges prominently from the Preamble of the Rome Statute, which refers to the determination to put an end to

\footnotetext{
171 Joseph William Davids, From Crimes Against Humanity to Human Rights Crimes, 18 NEW ENG J. INTL \& COMP. L. 225, 238-42 (2012).

172 Projects for an international criminal court had been around for decades. See, e.g., M. CHERIF BASSIOUNI, A DRAFT INTERNATIONAL CRIMINAL CODE AND DRAFT STATUTE FOR AN INTERNATIONAL CRIMINAL TRIBUNAL (1987).

173 Méndez, supra note 170, at 73.

174 Marlies Glasius, The International Criminal Court: A Global Civil Society ACHIEvement 26 (2006).

175 Id. at 37-44.

176 Janet Halley, Rape at Rome: Feminist Interventions in the Criminalization of Sex-Related Violence in Positive International Criminal Law, 30 MiCH. J. INT'L L. 1 (2008).

177 Rome Statute, supra note 25.

${ }_{178}$ Kofi Annan, Secretary-General Says Establishment of International Criminal Court is Gift of Hope to Future Generations: Meetings Coverage and Press Releases (1998), http://www.un.org/press/en/1998/19980720.sgsm6643.html.

${ }^{179}$ Robert Roth \& Françoise Tulkens, Introduction, 9 J. INT’L CRIM. JUST. 571, 571 (2011).
} 
"unimaginable atrocities that deeply shock the conscience of humanity." 180 The Court has also been entrusted "with almost mythical powers" including the management of transnational order and justice through criminal law. ${ }^{181}$ Yet, serious acts of violence are only captured through the lens of crimes. ${ }^{182}$ While human rights may be offered new prospects for enforcement through international criminal trials, the structural factors and socioeconomic injustices that contribute to human rights violations are systematically overlooked or reduced to "context". ${ }^{183}$

Initially, the widespread enthusiasm surrounding the ICC's creation obfuscated the limits of international criminal process in delivering justice for mass atrocities. ${ }^{184}$ In the last decade, however, disenchantment and criticism have substituted the initial euphoria. ${ }^{185}$ Great expectations of justice have been left unfulfilled by reality. International criminal justice promised to deter crime, end conflict, and bring about justice. ${ }^{186}$ However, only a little part of this has been delivered. Atrocities have not been deterred and the majority of international crimes remain unpunished. The focus only on certain countries has fomented accusations of racism and neocolonialism. ${ }^{187}$ Victims have hardly found redress, ${ }^{188}$ while the defendant's trial has been accused of embracing illiberal criminal

\footnotetext{
180 Rome Statute, supra note 25, pmbl.

${ }^{181}$ Frédéric Mégret, Three Dangers for the International Criminal Court: A Critical Look at a Consensual Project, 7 FINNISH Y.B. INT’L L. 193, 201 (2001).

182 ADAM BRANCH, DisPlaCing HUMAN RigHTS: WAR AND INTERVENTION IN NORTHERN UGANDA 182 (2011).

183 Sarah M. H. Nouwen \& Wouter G. Werner, Monopolizing Global Justice: International Criminal Law as Challenge to Human Diversity, 13 J. INT'L CRIM. JUST. 157 (2015).

184 Payam Akhavan, The International Criminal Court in Context: Mediating the Global and Local in the Age of Accountability, 97 AM. J. INT'L L.712, 712 (2003).

185 Joseph Powderly, International Criminal Justice in an age of Perpetual Crisis, 32 LEIDEN J. INT'L L. 1 (2019); Barrie Sander, International Criminal Justice as Progress: From Faith to Critique, in HISTORICAL ORIGINS OF INTERNATIONAL CRIMINAL LAW: VoL. 4, at 749 (Morten Bergsmo et al. eds., 2015); Darryl Robinson, Inescapable Dyads: Why the International Criminal Court Cannot Win, 28 LEIDEN J. INT’L L. 323 (2015).

186 UN Secretary-General, The Rule of Law and Transitional Justice in Conflict and Post-conflict Societies, U.N. Doc .S/2004/616 38 (2004).

187 Kamari MaXine Clarke, Fictions of Justice: THE International Criminal CourT AND THE CHALLENGE OF Legal Pluralism in Sub-SAHARAN AFrica (2009).

188 Sara Kendall \& Sarah Nouwen, Representational Practices at the International Criminal Court: The Gap Between Juridified and Abstract Victimhood, 76 L. \& CONTEMP. PROBS 235 (2013).
} 
doctrine. ${ }^{189}$ Yet, the common explanation for the "crisis" of international criminal justice is either lack of state support or deficiency in effectiveness, due to inadequate investigations or poor decision making. ${ }^{190}$ In other words, the aspirations of international criminal justice have reportedly been frustrated because there is not (good) enough international criminal law. The general commitment to international criminal justice stands firm because-it is said-_" [c]ertain things are simply wrong and ought to be punished." ${ }^{191}$ Human rights NGOs, in particular, deeply rely on international prosecution in their fight for justice. ${ }^{192}$ The advocacy work of many of them is so much framed in the terms of international criminal justice that they devote more time in lobbying support for international criminal institutions than in monitoring states' human rights compliance. ${ }^{193}$ There is also a different critique that questions the assumptions of international criminal law. ${ }^{194}$ For instance, some scholars have contended that not only are international criminal trials structurally incapable of addressing the socioeconomic causes of atrocities, but they also risk fostering other forms of impunity. ${ }^{195}$ However, the connection between human rights and international criminal law is rarely contested. ${ }^{196}$ Academics, practitioners, and NGOs, overwhelmingly agree that human rights are sources and raisons d'être of international criminal justice. ${ }^{197}$ Although prosecution of international

\footnotetext{
189 Darryl Robinson, The Identity Crisis of Criminal Law, 21 LEIDEN J. INT'L L. 925 (2008); George P. Fletcher \& Jens David Ohlin, Reclaiming Fundamental Principles of Criminal Law in the Darfur Case, 3 J. INT’L CRIM. JUST. 539 (2005).

190 Christine E. J. Schwöbel, Introduction, in CRITICAL APPROACHES TO INTERNATIONAL CRIMINAL LAW: AN INTRODUCTION 1, 3-4 (Christine E. J. Schwöbel ed., 2014).

191 David S. Koller, The Faith of the International Criminal Lawyer, 40 INT'L L. \& POL. 1019, 1033 (2008); Immi Tallgren, The Sensibility and Sense of International Criminal Law, 13 EUR. J. INT'L. 561, 564 (2002), quoting ANDREW VON HIRSCH, DOING JUstiCE: THE CHOICE OF PUNISHMENTS xxxix (1976).

192 Kjersti Lohne, Global Civil Society, the ICC, and Legitimacy in International Criminal Justice, in THE LEGITIMACY OF International Criminal Tribunals 449 (Nobuo Hayashi \& Cecilia M. Bailliet eds., 2017).

193 Id. at 459.

194 CRITICAL APPROACHES TO INTERNATIONAL CRIMINAL LAW, supra note 190.

195 Tor Krever, Ending Impunity? Eliding Political Economy in International Criminal Law, in RESEARCH HANDBOOK ON Political ECONOMY AND LaW 298-314 (Ugo Mattei \& John D. Haskell eds., 2015).

196 Christine E. J. Schwöbel, The Comfort of International Criminal Law, 24 L. \& CRITIQUE 169 (2013).

${ }^{197}$ Kjersti Lohne, NGOs for International Justice: Criminal or Victims' Justice?, in THE JUDICIALIZATION OF INTERNATIONAL LAW: A MiXed Blessing? 109, 127 (Andreas Føllesdal \& Geir Ulfstein eds., 2018); Meron, supra note 169; Gerry Simpson, Atrocity, law, Humanity: Punishing Human Rights Violators, in THE CAMBridge COMPANION TO HuMAN RIGHTS LAW 114, 124 (Conor Gearty \& Costas Douzinas eds., 2012).
} 
crimes may arguably raise threats to other human rights, especially defendants' rights, it remains undisputed that international criminal law pursues to some extent a human rights cause. ${ }^{198}$

International criminal law is "a penal regime without a state, and more generally without a sovereign." ${ }^{\text {"199 }}$ While domestic criminal law may find its normative legitimacy in the power of a central sovereign institution, international criminal law needs something else. Relying on a cosmopolitan approach, mainstream commentators argue that international criminal adjudication may rest on a value based order of humanity founded on "universal, indivisible and interculturally recognized human rights. ${ }^{200}$ International criminal law also derives part of its sociological and political legitimacy from a politics of representation of those who suffer human rights violations. ${ }^{201}$ Notably, victims and their "human rights entitlement to criminal justice" are one of the main justifying figures of the work of international criminal tribunals. ${ }^{202}$ These institutions invoke "the victim" as a means of backing the power they exercise, giving trials a human face, and showing why international criminal justice is valuable and needs financial support. ${ }^{203}$ Statute provisions and procedural rules on victims' protection, participation, and reparation have reinforced this focus. The ICC, in particular, was created with the aim of being also a "victims' court," with the goal of giving voice and restoration to those who suffered as a result of mass violence. ${ }^{204}$ Exercising justice on victims' behalf enables the action of international criminal tribunals but also places a high burden on

\footnotetext{
198 Andrew Clapham, Human Rights and International Criminal law, in THE CAMBRIDGE COMPANION TO INTERNATIONAL Criminal LAW, 11, 14-15 (William A. Schabas ed., 2016).

199 Markus D. Dubber, Common Civility: The Culture of Alegality in International Criminal Law, 24 LEIDEN J. INT'L L. 923,928 (2011).

200 Kai Ambos, Punishment Without a Sovereign? The Ius Puniendi Issue of International Criminal Law: A First Contribution Towards a Consistent Theory of International Criminal Law, 33 Oxford J. LEGAL STUD. 293, 308 (2013); Luigi D. A. Corrias \& Geoffrey M. Gordon, Judging in the Name of Humanity: International Criminal Tribunals and the Representation of a Global Public, 13 J. INT'L CRIM. JUST. 97 (2015). This approach is contested both by realists and critical scholars, see CARSTEN STAHN, A CRITICAL INTRODUCTION TO INTERNATIONAL CRIMINAL LAW 8-9 (2019).

201 Frédéric Mégret, The Anxieties of International Criminal Justice, 29 LEIDEN J. INT'L L. 197, 207 (2016).

${ }^{202}$ Frédéric Mégret, The Strange Case of the Victim Who Did Not Want Justice, 12 INT'L J. TranS'L JuST. 444, 445 (2018).

203 Kendall \& Nouwen, supra note 188, at 254; Sophie Rigney, Postcard From the ICTY, in INTERNATIONAL LAW'S OBJECTS 366 (Jessie Hohmann \& Daniel Joyce eds., 2018); ClARKE, supra note 187, at 108.

${ }^{204}$ ICC, Victims, https://www.icc-cpi.int/about/victims/Pages/default.aspx.
} 
them, when they fail to provide effective justice. ${ }^{205}$

The fight to end impunity in international criminal law is not limited to prosecution in international fora. International criminal law purports also to pervade the domestic level, by encouraging national prosecution and the implementation of criminal law mechanisms against serious human rights violations. The jurisdiction of the ICC, for example, is based on the principle of complementarity. ${ }^{206}$ On the one hand, the Court has jurisdiction over international crimes when states are unwilling or unable to prosecute. ${ }^{207}$ On the other, states are induced to undertake effective criminal investigations and trials if they want to avoid the intervention of the ICC (positive complementarity). ${ }^{208}$ In this way, complementarity encourages "heterogeneity in terms of the number of institutions adjudicating international crimes, but homogeneity in terms of the process they follow and the punishment they mete out." ${ }^{209}$ Moreover, while the 1990s was marked by a turn to international institutions on the assumption that domestic justice response would have been inadequate, ${ }^{210}$ in more recent years critiques and limitations of trials at the international stage have fostered the creation of tribunals that integrate both domestic and international structures. ${ }^{211}$ Hybrid and internationalized institutions include the Sierra Leone Special Court, the Extraordinary Chambers in the Courts of Cambodia, the Special Crimes Panels in Kosovo, followed by the Kosovo Specialist Chambers and Specialist Prosecutor's Office, the Special Panels and Serious

\footnotetext{
205 BRANCH, supra note 182, at 183.

206 See CARSTEN STAHN \& MOHAMED M. El ZEIDY, THE INTERNATIONAL CRIMINAL COURT AND COMPLEMENTARITY: FROM THEORY TO PRACTICE (2011).

207 Rome Statute, supra note 25, arts. 1, 17; SARAH M. H. NOUWEN, COMPLEMENTARITY IN THE LINE OF FIRE: THE CATALYSING EFFECT OF THE INTERNATIONAL CRIMINAL COURT IN UGANDA AND SUDAN (2013).

${ }^{208}$ ICC Assembly of States Parties, Report of the Bureau on Stocktaking: Complementarity, ICC-ASP/8/51 16 (2010). In the words of the ICC Appeals Chamber in Katanga, the complementarity principle "strikes a balance between safeguarding the primacy of domestic proceedings [. . . ] and the goal of the Rome Statute to "put an end to impunity."” [see ICC, Prosecutor v. Katanga, Judgment on the Appeal of Mr. Germain Katanga Against the Oral Decision of Trial Chamber II of 12 June 2009 on the Admissibility of the Case, ICC-01/04-01/07-1497, 85 (2009)].

${ }^{209}$ Mark A. Drumbl, Atrocity, Punishment, AND InTERnATIONAL LAW 143 (2007).

${ }^{210}$ STAHN, supra note 200, at 164-65.

211 Frédéric Mégret, In Defense of Hybridity: Towards a Representational Theory Of International Criminal Justice, 38 CORNELL INT’L L. J. 725 (2005).
} 
Crimes Unit in East Timor, the Special Tribunal for Lebanon, the War Crimes Chamber in Bosnia and Herzegovina, the Special Court in the Central African Republic, and the Extraordinary African Chamber. $^{212}$

To conclude, as long as international criminal trials adhere to due process standards, international criminal law is considered "the most civilized response" to advance the human rights regime. ${ }^{213}$ For this reason, the same advocates of prisoners' rights at the domestic level are often the most strenuous proponents of the desire to punish at the international level. ${ }^{214}$ International criminal law appears to fulfill a dual human rights mandate. It promotes fair trial and high standards of detention as models for national systems and it employs the preventive and retributive functions of criminal sentences to promote human rights standards. Whether international criminal law succeeds in these aims is another matter. ${ }^{215}$

\section{THE PENAL POLICY OF HUMAN RIGHTS BODIES}

During the last three decades, the IACtHR, the ECtHR, the UNHRC and other human rights bodies have interpreted their mandate in monitoring compliance with international conventions as comprising the imposition of obligations to criminalize, prosecute, and punish human rights violations. ${ }^{216}$ These institutions increasingly rely upon human rights law to order states to ensure

\footnotetext{
212 STAHN, supra note 200, at 197-210.

213 Cassese, supra note 163, at 271.

214 Stuart Beresford, Unshackling the Paper Tiger: The Sentencing Practices of the ad hoc International Criminal Tribunals for the Former Yugoslavia and Rwanda, 1 INT'L CRIM. L. REV. 33, 89 (2001); Robinson, supra note 189, at 930.

215 For a critique, see Martti Koskenniemi, "The Lady Doth Protest Too Much": Kosovo, and the Turn to Ethics in International Law, 65 MOD. L. REV. 159 (2002) (arguing that the desire to punish in international criminal law creates a dilemma between conducting a fair trial and performing a show trial).

216 Throughout the text, the term "human rights bodies" encompasses both regional human rights courts and international human rights monitoring bodies. For an overview, see Mattia Pinto, Awakening the Leviathan through Human
} 
criminal accountability at the domestic level, in a process that Alexandra Huneeus has defined as “international criminal law by other means." 217 The recourse to human rights instruments for enhancing criminal accountability is rooted in the doctrine of "positive obligations" and the theory of "horizontal applicability of human rights." 218 Since the 1980s, the traditional notion of human rights as freedom from state interference has shifted to a conception of rights that includes the state positive duty to remove barriers and ensure the full exercise of freedom. ${ }^{219}$ In addition, the growing awareness that mass abuses also originate from the conduct of private parties, other than the state, has resulted in an extension of human rights to relations between individuals. Today, wrongdoings committed by private actors may give rise to state responsibility if public authorities have failed to prevent them due to negligence or tolerance. ${ }^{220}$

The emergence of transitional justice in Latin America and Eastern Europe has also contributed to the development of case law on state obligations in criminal matters. Since the late 1980s, victims of mass abuses, often supported by NGOs, have relied on human rights bodies to seek criminal accountability when domestic systems have failed to try and punish wrongdoings committed by authoritarian regimes or in the aftermath of civil conflicts. ${ }^{221}$ In Latin America, deficiencies in accountability and widespread impunity encouraged many victims to seek remedy before the Organisation of American States (OAS) institutions. ${ }^{222}$ In Europe, the ECtHR evolving case law on criminal accountability is also a response to Turkey's and Russia's failures in bringing

Rights Law: How Human Rights Bodies Trigger the Application of Criminal Law, 34 UTRECHT J. INT'L \& EUR. L. 161 (2018); Anja SEIBERT-Fohr, Prosecuting Serious Human Rights Violations (2009).

217 Alexandra Huneeus, International Criminal Law by Other Means: The Quasi-Criminal Jurisdiction of the Human Rights Courts, 107 AM. J. INT'L L.1 (2013).

${ }^{218}$ Françoise Tulkens, The Paradoxical Relationship Between Criminal Law and Human Rights, 9 J. INT'L CRIM. JUST. 577,583 (2011).

219 Sandra Fredman, Human Rights Transformed: Positive Rights and Positive Duties (2008); Laurens Lavrysen, Human Rights in a Positive State: Rethinking the Relationship Between Positive and Negative Obligations Under the European CONVEntion On Human Rights 1-5 (2016).

${ }^{220}$ Danwood Mzikenge Chirwa, The Doctrine of State Responsibility as a Potential Means of Holding Private Actors Accountable for Human Rights, 5 MELB. J. INT'L L. 1 (2004).

221 Aldana-Pindell, supra note 28, at 608.

222 Sorochinsky, supra note 27, at 182. 
perpetrators to justice during and after the Kurdish and Chechnyan conflicts. ${ }^{223}$

In the context of the OAS, Velàsquez, Rodriguez v Honduras is not only the first IACtHR decision in a contentious case, but also the leading case of the Court's invocation of criminal accountability. ${ }^{224}$ The IACtHR found that states have a dual duty, namely to refrain from violations, but also to prevent, investigate, and punish them, regardless of whether state authorities are directly involved in the abuse. ${ }^{225}$ Yet, the OAS institution did not order Honduras to adopt criminal law measures as a remedy and acknowledged that " $[\mathrm{t}]$ he objective of international human rights law is not to punish those individuals who are guilty of violations." ${ }^{226}$ Nonetheless, the authority of this statement did not last long. In the mid-1990s, the Inter-American Court started prescribing states to effectively punish individual perpetrators. ${ }^{227}$ Today, the IACtHR case law refers to the failure to deploy criminal sanctions as a violation of human rights per se. In cases of torture and enforced disappearance the duty to punish has even attained the status of jus cogens. ${ }^{228}$

The ECtHR has also developed a body of case law on state obligations in criminal matters. ${ }^{229}$ The seminal case is $X$ and $Y v$ Netherlands. ${ }^{230}$ Here, the Court held that the "effective deterrence [that] is indispensable" to protect sexual integrity "can be achieved only by criminal-law provisions."231 Following this decision, the state duty to criminalize human rights abuses has been reiterated in the sphere of sexual life, ${ }^{232}$ but also with respect to the right to life, ${ }^{233}$ for cases of torture and inhuman

\footnotetext{
${ }^{223}$ Ruti Teitel, Transitional Justice and Judicial Activism: A Right to Accountability?, 48 CORNELL INT'L L. J. 385, 390 (2015).

${ }^{224}$ IACtHR, Velásquez Rodríguez v. Honduras, Series C No. 4 (1988).

${ }^{225} I d$. at 166.

226 Id. at 134.

${ }^{227}$ IACtHR, Caballero-Delgado and Santana v. Colombia, Series C No. 22, 72(5) (1995).

${ }^{228}$ IACtHR, Goiburú et al v. Paraguay, Series C No. 153, 84 (2006).

229 See Coercive Human Rights: Positive Duties to Mobilise the Criminal Law under the ECHR (Laurens Lavrysen \& Natasa Mavronicola eds., 2020); KREŠIMIR KAMBER, ProseCuTING HuMAN RIGHTS OfFENCES: RETHinking the Sword FunCtion of Human Rights Law (2017); ANDrEw Ashworth, Positive Obligations IN CRIMINAL LAW 8 (2013).

${ }^{230}$ ECtHR, X and Y v. Netherlands, App. No. 8978/80 (1985).

231 Id. at 27.

232 ECtHR, MC v. Bulgaria, App. No. 39272/98, 150 (2003).

233 ECtHR, Kiliç v. Turkey, App. No. 22492/93, 62 (2000).
} 
and degrading treatment, ${ }^{234}$ as well as for forced labor and human trafficking. ${ }^{235}$ Moreover, the ECtHR orders states to enforce their criminal law through "a thorough and effective investigation capable of leading to the identification and punishment of those responsible." 236 The European Court has recently clarified that, in case of serious bodily harm, civil compensation is not enough and prosecution is required. ${ }^{237}$ Finally, the ECtHR has begun to demand severe punishment for serious human rights violations. ${ }^{238}$ In the view of the European Court, the duty to resort to criminal law would lose much of its meaning if perpetrators were punished with too lenient a sanction. ${ }^{239}$

The UNHRC, for its part, has developed a similar case law concerning the duty to institute criminal proceedings for the defense of human rights, including for arbitrary killing, enforced disappearance, torture and ill treatment, sexual and domestic violence, and human trafficking. ${ }^{240}$ While in the 1980s the Committee merely required states "to bring to justice" those responsible for human rights violations, ${ }^{241}$ since the early 1990 s the UNHRC has explicitly demanded prosecution and punishment. ${ }^{242}$ The UN Committee Against Torture (UNCAT) is another human rights body that has consistently ordered states to investigate and punish acts of torture and ill treatment. ${ }^{243}$

From the jurisprudence of human rights bodies, criminal liability appears as an indispensable element of human rights protection, especially in cases of serious human rights abuses. The underlying rationales are mostly deterrence, prevention, and restoration of the rule of law. ${ }^{244}$ For

\footnotetext{
${ }^{234} \mathrm{ECtHR}, \mathrm{MC}$ v. Bulgaria, supra note 232, at 174.

235 ECtHR, Siliadin v. France, App. No. 73316/01, 89 (2005); ECtHR, CN v. United Kingdom, App. No. 4239/08, 8182 (2012); ECtHR, Rantsev v. Cyprus and Russia, App. No. 25965/04, 285 (2010).

236 ECtHR, Kaya v. Turkey, App. No. 158/1996/777/978, 107 (1998).

237 ECtHR [GC], Jeronovičs v. Latvia, App. No. 44898/10, 105 (2016).

238 ECtHR [GC], Gäfgen v. Germany, App. No. 22978/05, 124 (2010).

239 ECtHR [CG], Armani Da Silva v. United Kingdom, App. No. 5878/08, 286 (2016); ECtHR, Nikolova and Velichkova v. Bulgaria, App. No. 7888/03, 62 (2007).

240 UN Human Rights Committee, General Comment No. 31, U.N. Doc. CCPR/C/21/Rev.1/Add.13, 18 (2004).

241 UN Human Rights Committee, Barbato v. Uruguay, U.N. Doc. A/38/40, at 124, 11 (21 Oct. 1982).

${ }^{242}$ UN Human Rights Committee, Njaru v. Cameroon, U.N. Doc. CCPR/C/89/D/1353/2005, 8 (19 Mar. 2007$)$.

${ }^{243}$ CAT, Communication No. 353/2008 (decision on Ukraine), U.N. Doc. CAT/C/47/D/353/2008 (2011).

244 ECtHR, Opuz v Turkey, App. No. 33401/02, 128 (2009); IACtHR, Paniagua-Morales et al. v. Guatemala, Series C No. 37, 173 (1998); UN Human Rights Committee, supra note 240, at 18.
} 
human rights bodies, criminal law safeguards society by ending impunity and providing general human rights protection. All human rights bodies have also a tendency to require criminal accountability in the interests of individual victims. The OAS bodies, in particular, have the most radical approach. Since the decision in Paniagua Morales et al $v$ Guatemala, ${ }^{245}$ the IACtHR has had no hesitation in considering criminal justice as an instrument to protect the rights of the victims and give them restoration. ${ }^{246}$ For the Inter-American Court, prosecution and punishment ensure retrospective restoration of the infringed right but also enable the fulfilment of victims' right to have the perpetrator properly tried and punished. ${ }^{247}$ In the jurisprudence of the UNHRC, criminal investigation and prosecution are also a necessary remedy for human rights violations. ${ }^{248}$ Yet, unlike the IACtHR, the Committee does not explicitly recognize victims' right to the punishment of their offenders. In the jurisprudence of the ECtHR, criminal accountability is also at times deemed a measure of individual redress and satisfaction. In Al Nashiriv Romania and Abu Zubaydah v Lithuania, for instance, the ECtHR held that "the notion of an "effective remedy" for the victim entails criminal proceedings "leading to the identification and punishment of those responsible."249

In the jurisprudence of the IACtHR, the duty to deploy criminal sanction is absolute. The Court has often declared of no legal effect measures that frustrate criminal justice, including amnesty laws, statutes of limitations, the principle of non-retroactivity, and the prohibition against double jeopardy. ${ }^{250}$ Notably, opposition to amnesty appears entrenched in the OAS bodies' case law. ${ }^{251}$

\footnotetext{
245 IACtHR, Paniagua Morales et al. v. Guatemala, supra note 244.

${ }^{246} I d$. at $171-74$.

247 IACtHR, Villagrán Morales et al. v. Guatemala, Series C No 63, 253(8) (1999); Jesus-Maria Silva Sanchez, Doctrines Regarding the Fight Against Impunity and the Victim's Right for the Perpetrator to be Punished, 28 PACE L. REV. 865 (2008).

248 UN Human Rights Committee, Felipe and Evelyn Pestaño v. The Philippines, U.N. Doc. CCPR/C/98/D/1619/2007, 7.2-7.6 (2010).

${ }^{44}$ ECtHR, Al Nashiri v. Romania, App. No. 33234/12, 708, 709 (2018); ECtHR, Abu Zubaydah v. Lithuania, App. No. 46454/11, 673 (2018).

${ }^{250}$ IACtHR, Almonacid-Arellano et al v. Chile, Series C No. 154, 151, 154 (2006).

${ }^{251}$ Wayne Sandholtz \& Mariana Rangel Padilla, Juggling Rights, Juggling Politics: Amnesty Laws and the Inter-American Court, in FACUlTAD LATINOAMERICANA DE CIENCIAS SOCIALES: INTERNATIONAL STUdies AsSOCIATION JOINT
} 
Since Barrios Altos v. Peru, ${ }^{252}$ the IACtHR has extended the ban from self-amnesty laws to every amnesty shielding human rights abuses, regardless of their nature, origin, and purpose. ${ }^{253}$ Even amnesties upheld by popular referenda ${ }^{254}$ or aimed at promoting peace and reconciliation ${ }^{255}$ have been found inadmissible. ${ }^{256}$ Aversion to the state's use of amnesty is also visible in the case law of other human rights bodies. To date, the ECtHR has admitted that amnesties for serious human rights abuses might be acceptable in exceptional circumstances, ${ }^{257}$ whereas the UNHRC has imposed an absolute ban on amnesties shielding gross human rights violations. ${ }^{258}$ Both UNCAT $^{259}$ and the African Commission on Human and Peoples' Rights ${ }^{260}$ have adopted a similar position.

The case law on state obligations in criminal matters has had a considerable impact on domestic legal systems. Pursuant to human rights bodies' decisions, states have started new criminal investigations, overturned amnesties, introduced new offenses, and created new institutions to facilitate prosecution. ${ }^{261}$ In Simón, Julio Héctor y Otros, for instance, the Argentinian Supreme Court relied on the IACtHR case law to exclude the application of amnesty, statutory limitations, and the legality principle. ${ }^{262}$ In Italy, following a ECtHR decision, the Parliament approved a bill which

INTERNATIONAL CONFERENCE (2014), http://web.isanet.org/Web/Conferences/FLACSOISA\%20BuenosAires\%202014/Archive/5211d97f-650e-4bfd-b352-05f6a013929b.pdf; Christina Binder, The Prohibition of Amnesties by the Inter-American Court of Human Rights, 12 GERMAN L. J. 1203 (2011).

252 IACtHR, Barrios Altos v. Peru, Series C No. 76 (2001).

253 IACtHR, Massacres of El Mozote v. El Salvador, Series C No. 252 (2012).

254 IACtHR, Gelman v. Uruguay, Series C No. 221 (2011).

255 IACtHR, Gomes Lund et al v. Brazil, Series C No. 219 (2010).

256 Roberto Gargarella, No Place for Popular Sovereignty? Democracy, Rights, and Punishment in Gelman v. Uruguay, SELA (Seminario en latinoamérica de Teoría Constitucional y Política) Papers 1 (2013); Fabia Fernandes Carvalho Veçoso, Whose Exceptionalism? Debating the Inter-American View on Amnesty and the Brazilian Case, in ANTIIMPUNITY AND THE HUMAN RIGHTS AGENDA, supra note 4, at 185.

${ }^{257}$ ECtHR [GC], Marguš v. Croatia, App. No. 4455/10, 139 (2014); Miles Jackson, Amnesties in Strasbourg, 38 OxFORD J. LEGAL STUD. 451 (2018).

258 UN Human Rights Committee, Concluding Observations of the HRC: Croatia, U.N. Doc. CCPR/CO/71/HRV, 11 (2001).

259 UN Committee against Torture, General Comment No. 2, U.N. Doc. CAT/C/GC/2, 5 (2008).

260 ACHPR, Zimbabwe Human Rights NGO Forum v. Zimbabwe, AHRLR128, 215 (2006).

${ }^{261}$ Huneeus, supra note 217, at 2; Brian D. Tittemore, Ending Impunity in the Americas: The Role of the Inter-American Human Rights System in Advancing Accountability For Serious Crimes Under International Law, 12 SOUTHWESTERN J. L. \& TRADE IN THE AMERICAS 429, 449-60 (2005).

262 Supreme Court of Argentina, Simón, Julio Héctor y Otros, S.1767.XXXVIII (2005). 
aimed to introduce the crime of torture in the Italian Criminal Code. ${ }^{263}$ In the UK, ECtHR case law on state obligations to criminalize labor exploitation influenced the adoption of the Modern Slavery Act $2015 .^{264}$

To sum up, the case law of human rights bodies has evolved over time toward viewing criminal justice as a necessary means to promote and safeguard human rights. For some commentators this development is to be welcomed. ${ }^{265}$ Others, on the contrary, have argued that an expanded criminalization by means of human rights law may weaken the traditional commitment to the rights of the defendant, ${ }^{266}$ enhance state coercive power, ${ }^{267}$ or promote a "culture of conviction."268 Either way, criminal punishment has become one of the main objectives of human rights law. An in-depth analysis of human rights bodies' case law shows a tendency to assume an outright obligation to employ criminal law mechanisms. This obligation appears as something selfevident that needs no serious assessment concerning its practical and theoretical implications. ${ }^{269}$

\footnotetext{
263 Domenico Carolei, Cestaro v. Italy: The European Court of Human Rights on the Duty to Criminalise Torture and Italy's Structural Problem, 17 INT'L CRIM. L. REV. 567 (2017).

${ }^{264}$ Mattia Pinto, Sowing a "Culture of Conviction": What Shall Domestic Criminal Justice Systems Reap From Coercive Human Rights?, in Coercive Human Rights: Positive Duties to Mobilise the CRIMINAL LAw Under the ECHR 161 (Laurens Lavrysen \& Natasa Mavronicola eds., 2020); Virginia Mantouvalou, The UK Modern Slavery Act 2015 Three Years On, 81 MOD. L. REV. 1017 (2018).

265 Jens David Ohlin, The Right to Punishment for International Crimes, CORNELl LAw SCHOOL RESEARCH PAPER NO. 18-31, at 1-26 (2018); Sebastian Rădulețu, National Prosecutions as the Main Remedy in Cases of Massive Human Rights Violations: An Assessment of the Approach of the European Court of Human Rights, 9 INT'L J. TRAN'L JusT. 449 (2015); Keir Starmer, Human Rights, Victims and the Prosecution of Crime in the 21st Century, 11 CRIM. L. REV. 777 (2014); Binder, supra note 251; Tittemore, supra note 261.

266 Pinto, supra note 216; Basch, supra note 29; Daniel R. Pastor, La deriva neopunitivista de organismos y activistas como causa del desprestigio actual de los derechos humanos, JURA GENTIUM, 2006, http://www.juragentium.org/topics/latina/es/pastor.htm (last visited Apr 28, 2020); Ezequiel Malarino, Judicial Activism, Punitivism and Supranationalisation: Illiberal and Antidemocratic Tendencies of the Inter-American Court of Human Rights, 12 INTERNATIONAL CRIMINAL LAW REVIEW 665, 681-684 (2012).

267 Liora Lazarus, Positive Obligations and Criminal Justice: Duties to Protect or Coerce?, in PRINCIPLES AND VALUES IN CRIMINAL LAW AND CRIMINAL JUSTICE: ESSAYS IN HONOUR OF ANDREW ASHWORTH 135 (Lucia Zedner \& Julian V. Roberts eds., 2012); Natasa Mavronicola, Taking Life and Liberty Seriously: Reconsidering Criminal Liability Under Article 2 of the ECHR: Taking Life and Liberty Seriously, 80 MOD. L. REV. 1026 (2017).

268 Frédéric Mégret \& Jean-Paul Calderón, The Move Towards a Victim-Centred Concept of Criminal Law and The "Criminalization" of Inter-American Human Rights Law: A Case of Human Rights Law Devouring Itself?, in THE INTERAmerican Court of Human Rights: Theory And Practice, Present And Future 419 , 438 (Yves Haeck, Oswaldo Ruiz-Chiriboga, \& Clara Burbano-Herrera eds., 2015); Pinto, supra note 264.

${ }^{269}$ Pinto, supra note 216, at 176.
} 


\section{CONCLUSION}

Prince Mohammed Bin Salman is still ruling Saudi Arabia, but the human rights movement is not sitting on its hands. In June 2019, the UN Special Rapporteur on Extrajudicial, Summary or Arbitrary Killings, Agnès Callamard, submitted to the UN Human Rights Council her final report of a human rights inquiry into the killing of Jamal Khashoggi. ${ }^{270}$ First, the Special Rapporteur found that Saudi Arabia bears responsibility for the extrajudicial killing of the journalist, in violation of the right to life, the prohibition against enforced disappearance, the protection of freedom of expression and, probably, the prohibition of torture. Second, she maintained that Saudi Arabia and Turkey have failed to comply with the positive obligation to investigate Khashoggi’s killing, and that Saudi Arabia has also violated its duty to prosecute human rights violations and provide reparation to the journalist's family. Third, relying on a possible violation of the Torture Convention, she found that Khashoggi's murder constitutes an international crime over which states should claim universal jurisdiction. Finally, the Special Rapporteur called on various UN bodies to initiate an international criminal investigation into Khashoggi's death and, possibly, establish an ad hoc or hybrid tribunal for providing judicial accountability.

While the traditional understanding of human rights is to restrain state authority to prevent abuses against the individual, in the last few decades human rights have been recast in a way that has made criminal law one of the main instruments for their promotion. Since the 1970s, human rights have allowed penal power to move across borders and, through the interactions among different

270 Special Rapporteur on Extrajudicial, Summary or Arbitrary Executions, Report of the Special Rapporteur On Extrajudicial, Summary or Arbitrary Executions: Investigation of, Accountability for and Prevention of Intentional State Killings of Human Rights Defenders, Journalists and Prominent Dissidents (2019); Special Rapporteur on Extrajudicial, Summary or Arbitrary Executions, Annex to the Report of the Special Rapporteur on Extrajudicial, Summary or Arbitrary Executions: Investigation into the Unlawful Death of Mr. Jamal Khashoggi (2019). 
actors, norms, and law levels, they have shaped penal policies around the world. In many countries, the language of victims' rights, at times combined with human rights discourse, has become a vehicle for the legitimation of criminal law measures. The same language has also played a key role in justifying a new focus of international criminal law on atrocities and human rights bodies' recourse to criminal justice. Furthermore, since the adoption of the Torture Convention, a number of international instruments adopted under the aegis of the UN have prescribed criminal law mechanisms for breaches of human rights standards. These instruments have been invoked to foster accountability for human rights abuses of past regimes when many countries around the world began their transition to democracy at the end of the Cold War. Finally, human rights bodies have assumed criminal law obligations under human rights conventions. In so doing, not only they have complemented the role of international criminal tribunals in enforcing human rights through criminal justice, but they have also encouraged states to deploy their domestic criminal system to counter impunity.

Driven by the universality of human rights discourse, criminal justice projects have expanded over time and across spaces, mixing domestic and international elements. Victims' rights advocates, NGOs, academics, judges, policymakers, and other state and non-state actors have been involved in this process. While deployed to protect human rights, penality has been strengthened, defended, and justified. In what may appear as a paradox, rather than moderating state penal policies, the more human rights have permeated conceptions of justice around the globe, the greater has been the dissemination and legitimation of punitive responses. The expansion of penality by reference to human rights has been welcomed almost universally with few critical voices raised and limited serious debate. It has been normalized. Yet, we have become accustomed to requiring penal action for human rights abuses without interrogating what is involved in the relationship between two bodies of law, as human rights, and criminal law, that are at once very different but entangled. It is 
now time to explore this taken-for-granted relationship to expose the assumptions that lie behind it and the interests it supports. 